\title{
Cellular Form of Prion Protein Inhibits Reelin-Mediated Shedding of Caspr from the Neuronal Cell Surface to Potentiate Caspr-Mediated Inhibition of Neurite Outgrowth
}

\author{
Vasudharani Devanathan, ${ }^{1,2}$ Igor Jakovcevski, ${ }^{1 \star}$ Antonella Santuccione, ${ }^{1 *}$ Shen Li, ${ }^{1}$ Hyun Joon Lee, ${ }^{1}$ Elior Peles, ${ }^{5}$ \\ Iryna Leshchyns'ka, ${ }^{1,3}$ Vladimir Sytnyk, ${ }^{1,3}$ and Melitta Schachner ${ }^{1,4}$ \\ ${ }^{1}$ Zentrum für Molekulare Neurobiologie, Universität Hamburg, 20246 Hamburg, Germany, ${ }^{2}$ Department of Pharmacology and Experimental Therapy, \\ Institute of Experimental and Clinical Pharmacology and Toxicology, Eberhard Karls University Hospitals and Clinics and Interfaculty Center of \\ Pharmacogenomics and Pharmaceutical Research, University of Tübingen, 72074 Tübingen, Germany, ${ }^{3}$ School of Biotechnology and Biomolecular \\ Sciences, University of New South Wales, Sydney, New South Wales 2052, Australia, ${ }^{4}$ Keck Center for Collaborative Neuroscience, Rutgers University, \\ Piscataway, New Jersey 08854-8082, and ${ }^{5}$ Department of Molecular Cell Biology, Weizmann Institute of Science, Rehovot 76100, Israel
}

Extension of axonal and dendritic processes in the CNS is tightly regulated by outgrowth-promoting and -inhibitory cues to assure precision of synaptic connections. We identify a novel role for contactin-associated protein (Caspr) as an inhibitory cue that reduces neurite outgrowth from CNS neurons. We show that proteolysis of Caspr at the cell surface is regulated by the cellular form of prion protein (PrP), which directly binds to Caspr. PrP inhibits Reelin-mediated shedding of Caspr from the cell surface, thereby increasing surface levels of Caspr and potentiating the inhibitory effect of Caspr on neurite outgrowth. PrP deficiency results in reduced levels of Caspr at the cell surface, enhanced neurite outgrowth in vitro, and more efficient regeneration of axons in vivo following spinal cord injury. Thus, we reveal a previously unrecognized role for Caspr and PrP in inhibitory modulation of neurite outgrowth in CNS neurons, which is counterbalanced by the proteolytic activity of Reelin.

\section{Introduction}

Cellular prion protein $(\mathrm{PrP})$ is an adhesion molecule implicated in neuronal survival, neurite outgrowth (Chen et al., 2003; Santuccione et al., 2005), and synaptic function (Collinge et al., 1994). This functional feature of PrP is consistent with its association with several cell surface proteins involved in regulation of neural development, including the $67 \mathrm{kDa}$ laminin receptor, the 37 $\mathrm{kDa}$ laminin receptor precursor protein, and the extracellular matrix glycoprotein laminin (Rieger et al., 1997; Graner et al., 2000; Gauczynski et al., 2001). PrP also occurs in a complex with the neural cell adhesion molecule (NCAM) (Schmitt-Ulms et al.,

\footnotetext{
Received Nov. 15, 2009; revised April 7, 2010; accepted May 16, 2010.

We are grateful to Dr. Martin H. Groschup (Institute for Novel and Emerging Infectious Diseases, Greifswald, Germany) and Dr. Charles Weissmann (Department of Infectology, Scripps Florida, Jupiter, FL) for PrP ${ }^{-1-}$ mice, Dr. Michael Frotscher and Dr. Shanting Zhao (Institute for Anatomy and Cell Biology, Albert-Ludwigs-University of Freiburg, Freiburg, Germany) for Reelin ${ }^{+/+}$and Reelin ${ }^{-1-}$ brains, Dr. Man Sun Sy (Case Western Reserve University, Cleveland, $\mathrm{OH}$ ) for monoclonal antibody 8H4 against PrP, Dr. Cathérine Faivre-Sarrailh (Institut Jean Roche, Marseille, France) for antibodies against Caspr, Dr. Tom Curran (St. Jude Children's Research Hospital, Memphis, TN) for the Reelin plasmid, Dr. Gianfranco Gennarini (University of Bari, Bari, Italy) for the contactin plasmid, and Dr. Sylvain Lehmann (Institut de Génétique Humaine du Centre National de la Recherche Scientifique, Montpellier, France) for the PrP plasmid.

*I.J. and A.S. contributed equally to this work.

Correspondence should be addressed to either of the following: Melita Schachner, Keck Center for Collaborative Neuroscience, Rutgers, University, 604 Allison Road, Piscataway, NJ 08854-8082, E-mail: schachner@biology. rutgers.edu; or Vladimir Sytnyk, School of Biotechnology and Biomolecular Sciences, University of New South Wales, Sydney, New South Wales 2052, Austrlia, E-mail: v.sytnyk@unsw.edu.au.

A. Santuccione's present address: Division of Psychiatry Research, University of Zurich, August-Forel-Strasse 1, 8008 Zurich, Switzerland.

DOI:10.1523/JNEUROSC1.5657-09.2010

Copyright $\odot 2010$ the authors $\quad 0270-6474 / 10 / 309292-14 \$ 15.00 / 0$
}

2001) that results from cis- and trans-interactions between $\operatorname{PrP}$ and NCAM at the neural cell surface (Santuccione et al., 2005). PrP promotes recruitment of NCAM to lipid rafts and thereby regulates activation of fyn kinase, an enzyme implicated in NCAM- and PrP-mediated intracellular signaling (Beggs et al., 1994, 1997; Mouillet-Richard et al., 2000; Bodrikov et al., 2005, 2008). PrP also associates with the $\alpha_{2} / \beta_{2}-\mathrm{Na}^{+} / \mathrm{K}^{+}$-ATPase, which in turn associates with the Ig superfamily adhesion molecule basigin (Kleene et al., 2007). This complex between PrP, $\alpha_{2} / \beta_{2}$-ATPase, and basigin regulates the transport of lactate in astrocytes via the monocarboxylate transporter 1 , which is activated by the synaptic GluR2 subunit-containing AMPA receptor with which PrP also interacts (Kleene et al., 2007).

It is conceivable that reduction in the functions of PrP by its conversion into the pathological form ( $\left.\mathrm{PrP}^{\text {scrapie }}\right)$ renders the cellular form of PrP less available to the normal cellular functions, thereby contributing to the pathology of prion diseases. Since an understanding of prion diseases also depends on the identification of binding partners for the cellular form of prion protein and the characterization of their functional properties, we searched for other binding partners of $\operatorname{PrP}$ with the aim of widening our understanding of the functions of $\mathrm{PrP}$ in the context of its interactions with molecules at the cell surface and/or in the extracellular matrix.

Here, we report on the interaction of $\operatorname{PrP}$ and contactinassociated protein (Caspr) (Peles et al., 1997). Caspr is most well characterized as an adhesion molecule that is required for the formation of axoglial paranodal junctions surrounding the nodes 
of Ranvier in myelinated axons (Einheber et al., 1997; Scherer, 1999; Peles and Salzer, 2000). We now show a novel function for Caspr as a negative regulator of neurite outgrowth in CNS neurons. While it was shown previously that Caspr associates in cis-interaction with the glycosylphosphatidyl inositol (GPI)anchored neural cell adhesion molecule contactin/F3 (Peles et al., 1997), which is required for the transport of Caspr to the cell surface (Faivre-Sarrailh et al., 2000), we provide evidence that the interaction with GPI-anchored PrP prevents Caspr from shedding at the cell surface. Furthermore, we identified Reelin, an extracellular matrix glycoprotein with protease activity (Quattrocchi et al., 2002), as an enzyme involved in shedding of Caspr. Thus, we reveal a previously unrecognized role for Caspr and PrP in inhibitory modulation of neurite outgrowth in neurons, which is counterbalanced by the proteolytic activity of Reelin.

\section{Materials and Methods}

Antibodies. Mouse monoclonal antibody $8 \mathrm{H} 4$ against $\mathrm{PrP}$, a generous gift from Dr. Man Sun Sy (Case Western Reserve University, Cleveland, $\mathrm{OH}$ ), was used for immunocytochemistry and immunohistochemsitry. The specificity of the antibody was verified in PrP-transfected Chinese hamster ovary $(\mathrm{CHO})$ cells (supplemental Fig. S1, available at www. jneurosci.org as supplemental material) and $\mathrm{PrP}^{-1-}$ brains. Rat monoclonal antibody 555 against L1 (Appel et al., 1993) was used for immunocytochemistry and immunoblotting. Rabbit polyclonal antibodies against the extracellular domain of Caspr (L23, L17), a kind gift from Cathérine Faivre-Sarrailh (Institut Jean-Roche, Marseille, France), were used for immunocytochemistry and neurite outgrowth experiments. Polyclonal goat antibodies against the N terminus of Caspr (N15) from Santa Cruz Biotechnology were used for immunocytochemistry, Western blot, and neurite outgrowth experiments. Goat polyclonal antibodies against PrP (M20) (Santa Cruz Biotechnology) were used for immunoprecipitation and Western blot analysis. Mouse monoclonal antibody against Reelin (Millipore) was used for Western blot analysis and immunohistochemistry. Polyclonal rabbit and monoclonal mouse antibodies against calbindin (Sigma) were used for immunohistochemistry. For Western blot we also used polyclonal rabbit antibodies against the FGF receptor (Flg) (Santa Cruz Biotechnology), polyclonal rabbit antibodies against CHL1 (Leshchyns'ka et al., 2006), polyclonal rabbit antibodies against actin and mouse monoclonal antibodies against tubulin (Sigma), polyclonal goat antibodies against contactin ( $\mathrm{R} \& \mathrm{D}$ Systems), mouse monoclonal antibody against glyceraldehyde 3-phosphate dehydrogenase (GAPDH), and rabbit polyclonal antibodies against 5-hydroxytryptamine transporter (5-HT) and tyrosine hydroxylase (TH) (Millipore). Secondary antibodies against goat, rabbit, rat, and mouse Igs coupled to Cy2, Cy3, Cy5, or HRP were from Dianova.

Production of the polyclonal antibodies against the intracellular domain of Caspr. Polyclonal antibodies against the intracellular domain of Caspr were generated by immunizing rabbits with a peptide derived from the Caspr intracellular domain (H-APGPRDQNLPQILEESRSEC-OH). Imject Maleimide Activated McKLH kit (Pierce) was used for conjugating the peptide to a carrier protein for animal injections. Rabbits were killed after five boosts and the blood was collected and processed to collect the serum. Antiserum thus obtained was purified further by affinity chromatography using protein G-Sepharose 4 fast flow column. Bound antibodies were eluted using $0.1 \mathrm{M}$ glycine ( $\mathrm{pH}$ 2.7-3.0). Eluted material was neutralized with $1 \mathrm{~m}$ Tris- $\mathrm{HCl}, \mathrm{pH} 8.8$, and dialyzed extensively against PBS, $\mathrm{pH}$ 7.3. The specificity of the purified antibodies was confirmed in Caspr transfected CHO cells (supplemental Fig. S1, available at www.jneurosci.org as supplemental material). The antibodies were used for biochemical, histochemical, and cytochemical studies.

Animals. PrP ${ }^{-1-}$ mice (Bueler et al., 1992) were generously provided by Dr. Martin H. Groschup (Institute for Novel and Emerging Infectious Diseases, Greifswald, Germany). Caspr ${ }^{-1-}$ mice were as described previously (Gollan et al., 2003). Young (10 d old) or adult (6-10 week old) wild-type, $\mathrm{PrP}^{-1-}$, and $\mathrm{Caspr}^{-1-}$ animals were used as indicated in the text. Brains of 10-d-old Reelin ${ }^{+/+}$and Reelin ${ }^{-1-}$ mice were generously provided by Dr. Michael Frotscher and Dr. Shanting Zhao (Institute for Anatomy and Cell Biology, Albert-Ludwigs-University of Freiburg, Freiburg, Germany).

Plasmids. The Reelin plasmid was a kind gift from Dr. Tom Curran (St. Jude Children's Research Hospital, Memphis, TN). The full-length Caspr plasmid was as described previously (Peles et al., 1997). Caspr-Fc encoding the extracellular domain of rat Caspr fused to human Fc (Gollan et al., 2003) was subcloned into pcDNA3 and used to transfect CHO cells that secrete this protein into the culture medium. The contactin plasmid was a kind gift from Dr. Gianfranco Gennarini (University of Bari, Bari, Italy). PrP plasmids were kind gifts of Dr. Sylvain Lehmann (Institut de Génétique Humaine du CNRS, Montpellier, France).

Purification of Caspr. Caspr was purified from brain homogenates using polyclonal antibodies against the intracellular domain of Caspr with the Bio-Rad Econo system. Antibodies were coupled to cyanogen bromide-activated Sepharose according to the manufacturer's instructions (GE Healthcare). Brains from adult mice were homogenized in buffer containing $5 \mathrm{~mm}$ Tris, $\mathrm{pH}$ 7.5, $0.32 \mathrm{~m}$ sucrose, $1 \mathrm{~mm} \mathrm{CaCl}_{2}, 1 \mathrm{~mm}$ $\mathrm{MgCl}_{2}$, and $1 \mathrm{~mm} \mathrm{NaHCO}, 0.5 \%$ Nonidet P-40, and EDTA-free Complete Protease Inhibitor Cocktail (Roche) and centrifuged at $2000 \times \mathrm{g}$ for $15 \mathrm{~min}$ at $4^{\circ} \mathrm{C}$. The supernatant was then collected and lysed overnight at $4^{\circ} \mathrm{C}$ by adding $\mathrm{N}$-octylglucoside and Triton X-100 to a final concentration of 1 and $0.5 \%$, respectively. The lysate was centrifuged at $50,000 \times g$ for $1 \mathrm{~h}$ at $4^{\circ} \mathrm{C}$. The resulting supernatant was collected and applied to the column containing immobilized polyclonal antibodies against Caspr. Bound proteins were eluted with $50 \mathrm{~mm}$ ethanolamine, $\mathrm{pH} 11.5,150 \mathrm{~mm}$ $\mathrm{NaCl}$, and $0.2 \% 3$ - [(3-cholamidopropyl)dimethylammonio]-1-propanesulfonate and immediately neutralized with $1 \mathrm{~m}$ Tris- $\mathrm{HCl}, \mathrm{pH} 6.8$. Protein-containing fractions were collected, dialyzed overnight at $4^{\circ} \mathrm{C}$ against TBS, and verified for the presence of Caspr by SDS-PAGE, followed by silver staining.

ELISA. L1-Fc $(2 \mu \mathrm{g} / \mathrm{ml})$ (Chen et al., 1999), PrP-Fc $(2 \mu \mathrm{g} / \mathrm{ml})$ (Chen et al., 2003), and BSA $(2 \mu \mathrm{g} / \mathrm{ml})$ were immobilized on the polyvinylchloride surface of a 96-well microtiter plate in PBS overnight at $4^{\circ} \mathrm{C}$. Nonabsorbed proteins were removed and wells were washed five times for $5 \mathrm{~min}$ at room temperature (RT) with PBS containing 0.05\% Tween 20 (PBS$\mathrm{T})$. Wells were blocked for $1 \mathrm{~h}$ at RT with $1 \%$ BSA in PBS and subsequently incubated with different concentrations of Caspr $(0-2 \mu \mathrm{g} / \mathrm{ml})$ in PBS-T containing 3\% BSA for $2 \mathrm{~h}$ at RT. Wells were then washed five times for 5 min each at RT with PBS-T, and bound Caspr was detected with Caspr antibodies followed by HRP-conjugated secondary antibodies visualized by detecting HRP with 2,2'-azino-bis(3-ethylbenzthiazoline-6sulfonic acid reagent, which resulted in a colored product that was quantified using an ELISA reader at $405 \mathrm{~nm}$.

Brain and spinal cord homogenate preparation. Whole brains or the 5-mm-long segments from the spinal cord lesion scar were taken for analysis. Homogenates were prepared using a Potter homogenizer in 50 mм Tris- $\mathrm{HCl}$ buffer, $\mathrm{pH} 7.5$, containing $0.32 \mathrm{M}$ sucrose, $1 \mathrm{~mm} \mathrm{CaCl}, 1$ $\mathrm{mM} \mathrm{MgCl}_{2}, 1 \mathrm{~mm} \mathrm{NaHCO}$, and Complete Protease Inhibitor Cocktail (Roche).

Isolation of the total membrane fraction. Brain homogenates were prepared using a Potter homogenizer in HOMO buffer $\left(1 \mathrm{mM} \mathrm{MgCl}_{2}, 1 \mathrm{mM}\right.$ $\mathrm{CaCl}_{2}, 1 \mathrm{~mm} \mathrm{NaHCO}, 5 \mathrm{~mm}$ Tris, $0.32 \mathrm{~m}$ sucrose, $\mathrm{pH}$ 7.4) and centrifuged at $700 \times g$ for $10 \mathrm{~min}$ at $4^{\circ} \mathrm{C}$. The resulting supernatants were centrifuged at $100,000 \times g$ at $4^{\circ} \mathrm{C}$ for $30 \mathrm{~min}$. Pellets containing the total membrane fraction were used for further analyses.

Isolation of growth cones. Growth cones were isolated as described previously (Pfenninger et al., 1983). Brain homogenates from 1- to 3-dold mice were centrifuged at $1660 \times g$ for $15 \mathrm{~min}$ at $4^{\circ} \mathrm{C}$. The supernatant was collected and centrifuged on a discontinuous density gradient of $0.75 / 1.0 / 2.66 \mathrm{M}$ sucrose at $242,000 \times g$ for $40 \mathrm{~min}$ at $4^{\circ} \mathrm{C}$. The interface between the load and $0.75 \mathrm{~m}$ sucrose containing growth cones was collected, resuspended in $10 \mathrm{ml}$ of HOMO buffer, and pelleted by centrifugation at $100,000 \times g$ for $40 \mathrm{~min}$ at $4^{\circ} \mathrm{C}$ to obtain purified growth cones.

Coimmunoprecipitation. Homogenates ( $1 \mathrm{mg}$ of protein) were lysed for $30 \mathrm{~min}$ in $50 \mathrm{~mm}$ Tris- $\mathrm{HCl}$ buffer, $\mathrm{pH}$ 7.5, containing $150 \mathrm{~mm} \mathrm{NaCl}$, $1 \%$ Nonidet P-40, $1 \%$ octyl-D-glucopyranoside or $0.5 \%$ SDS, $1 \mathrm{~mm} \mathrm{NaF}$, $2 \mathrm{mM} \mathrm{Na}_{3} \mathrm{VO}_{4}, 0.1 \mathrm{~mm}$ PMSF, and EDTA-free Protease Inhibitor Cock- 
tail (Roche). The lysis buffer containing this combination of detergents completely solubilizes lipid rafts and has been used in a number of studies involving coimmunoprecipitation of lipid raft components (Trupp et al., 1999; Paratcha et al., 2001; Santuccione et al., 2005). Samples were then centrifuged for $15 \mathrm{~min}$ at $20,000 \times g$ and $4^{\circ} \mathrm{C}$. Supernatants were cleared with protein A/G-agarose beads (Santa Cruz Biotechnology) for $3 \mathrm{~h}$ at $4^{\circ} \mathrm{C}$ and incubated with respective primary antibodies overnight at $4^{\circ} \mathrm{C}$, followed by precipitation with protein A/G-agarose beads applied for $3 \mathrm{~h}$ at $4^{\circ} \mathrm{C}$. The beads were washed three times with lysis buffer and once with PBS, and bound proteins analyzed by immunoblotting.

Western blot analysis. Samples were mixed with sample buffer and boiled for 5-7 min. Proteins were separated by electrophoresis on 8,10 , or $12 \%$ SDS-polyacrylamide gels, depending on the molecular weight of the proteins that were analyzed, and transferred to a nitrocellulose membrane (GE Healthcare). Membranes were blocked with 5\% milk in PBS, incubated with primary antibodies overnight at $4^{\circ} \mathrm{C}$ (or for $3 \mathrm{~d}$ at $4^{\circ} \mathrm{C}$ for supernatant analysis) with shaking and washed with PBS. Primary antibodies were detected with corresponding HRP-conjugated secondary antibodies applied for $1 \mathrm{~h}$ in 5\% milk in PBS. After washing, secondary antibodies were visualized with chemiluminescence.

In vitro proteolytic processing by Reelin. Caspr-Fc, or Caspr or L1 purified from mouse brain were incubated at $37^{\circ} \mathrm{C}$ for $2 \mathrm{~h}$ with Reelincontaining culture medium from $\mathrm{CHO}$ cells transfected with full-length Reelin or medium from $\mathrm{CHO}$ cells transfected with pcDNA3 for control. Samples were then resuspended in sample buffer, boiled for $8 \mathrm{~min}$, and analyzed by Western blot.

Cerebellar granule cell cultures. Dissociated granule cell cultures were prepared from the cerebellum of 6- to 8-d-old wild-type, $\mathrm{PrP}^{-1-}$, and $\mathrm{Caspr}^{-1-}$ mice as described previously (Chen et al., 1999).

CHO cell culture. $\mathrm{CHO}$ cells were maintained in Glasgow modified Eagle's medium containing 10\% fetal calf serum and transfected using Lipofectamine with Plus reagent (Invitrogen) following the manufacturer's instructions.

Immunocytochemistry. Indirect immunofluorescence staining was performed as described previously (Sytnyk et al., 2002; Leshchyns'ka et al., 2003). Neurons on glass coverslips were washed in PBS and fixed in $4 \%$ formaldehyde in PBS for 15 min at RT. Neurons were then washed three times with PBS, permeabilized with $0.25 \%$ Triton X-100 in PBS applied for $5 \mathrm{~min}$, blocked in 1\% BSA in PBS, and incubated with primary antibodies diluted in 1\% BSA in PBS for $1 \mathrm{~h}$. Primary antibodies were detected with corresponding secondary antibodies applied in $1 \%$ BSA in PBS for 30 min. To detect Caspr at the cell surface, polyclonal antibodies against the extracellular domain of Caspr were applied to live neurons for $20 \mathrm{~min}$ in culture medium in a $\mathrm{CO}_{2}$ incubator, followed by secondary antibodies applied for $15 \mathrm{~min}$ in culture medium in a $\mathrm{CO}_{2}$ incubator. In cocapping experiments, antibodies against the extracellular domains of $\operatorname{PrP}$ and Caspr were applied together in culture medium for $15 \mathrm{~min}$, followed by secondary antibodies applied in culture medium for $15 \mathrm{~min}$ in a $\mathrm{CO}_{2}$ incubator. Coverslips were embedded in Aqua-Poly/ Mount (Polysciences). Images were acquired at RT using a confocal laser-scanning microscope TCS-SP2 (Leica) using a $63 \times$ objective. The images were exported using LSM510 software (version 3; Zeiss).

Neurite outgrowth assay. Cells were maintained in 12-well plates (Nunc) on glass coverslips (15 mm in diameter; Hecht) substrate coated with poly-L-lysine (Sigma) followed, when indicated, with Caspr antibodies $(1 \mu \mathrm{g} / \mathrm{ml})$, laminin (Sigma; $1 \mu \mathrm{g} / \mathrm{ml})$, or PrP-Fc $(1 \mu \mathrm{g} / \mathrm{ml})$ and cultured in chemically defined serum-free medium (Chen et al., 1999). Where indicated, aprotinin $(1 \mu \mathrm{M})$ was added to the medium. Twentytwo hours after seeding, cells were fixed for 15 min with $2.5 \%$ glutaraldehyde in PBS and stained with toluidine blue/trypan blue. The total length of all neurites per neuron was measured by the KS image analysis system (Kontron-Zeiss). At least three coverslips for each group were taken in each experiment, and at least 100 cells from one coverslip were analyzed. Experiments were repeated three times.

Analysis of Caspr shedding into the culture medium. Inhibitors [aproti$\operatorname{nin}(1 \mu \mathrm{M}$; Sigma), pepstatin ( $1 \mu \mathrm{M}$; Sigma), phenanthrolamine (10 $\mu \mathrm{M}$; Sigma), GM6001 (1 $\mu \mathrm{M}$; Merck)] or PrP-Fc $(1 \mu \mathrm{g} / \mathrm{ml})$ were applied $6 \mathrm{~h}$ after plating of cells. Cells were maintained for $5 \mathrm{~d}$ by replacing medium and inhibitors or PrP-Fc every second day. Culture medium was then collected. Proteins in the culture medium were concentrated by Amicon columns with a $10 \mathrm{kDa}$ molecular weight cutoff (Millipore) and used for Western blot analysis.

Cell surface biotinylation. Surface biotinylation was performed as described previously (Schmidt et al., 1997) with modifications. Briefly, $48 \mathrm{~h}$ after transfection cells were washed twice with ice-cold PBS supplemented with $0.5 \mathrm{~mm} \mathrm{CaCl}_{2}$ and $2 \mathrm{~mm} \mathrm{MgCl}_{2}$ (PBSCM). Surface proteins were biotinylated by incubating cells with $0.5 \mathrm{mg} / \mathrm{ml}$ sulfo-NHS-LSbiotin (Pierce) in PBSCM for $10 \mathrm{~min}$ at $4^{\circ} \mathrm{C}$. Biotinylation was terminated by incubation with $20 \mathrm{~mm}$ glycine in PBSCM at $4^{\circ} \mathrm{C}$ for $10 \mathrm{~min}$, followed by extensive washing with PBSCM. Biotinylated cells were then lysed for $30 \mathrm{~min}$ in $50 \mathrm{~mm}$ Tris- $\mathrm{HCl}$ buffer, $\mathrm{pH} 7.5$, containing $150 \mathrm{~mm}$ $\mathrm{NaCl}, 0.5 \%$ Triton X-100, $1 \mathrm{~mm} \mathrm{NaF}, 2 \mathrm{~mm} \mathrm{Na}_{3} \mathrm{VO}_{4}, 0.1 \mathrm{~mm}$ PMSF, $1 \mathrm{~mm}$ $\mathrm{Na}_{4} \mathrm{P}_{2} \mathrm{O}_{7}, 1 \mathrm{~mm}$ EDTA, and EDTA-free Protease Inhibitor Cocktail (Roche) and centrifuged at $700 \times g$ for $15 \mathrm{~min}$ at $4^{\circ} \mathrm{C}$. The supernatants were collected and protein concentrations were determined using the BCA kit (Pierce). The amounts of surface-localized proteins were determined by precipitating biotinylated proteins with streptavidin-coupled agarose beads (Pierce) applied to the supernatants at $4^{\circ} \mathrm{C}$ overnight. Agarose beads were pelleted by centrifugation and washed twice with the lysis buffer. Precipitated proteins were solubilized by the addition of $2 \times$ Laemmli buffer to the agarose beads and analyzed by Western blot.

Subcellular fractionation and isolation of lipid-enriched microdomains. Lipid rafts were prepared from the crude membrane fraction of brain homogenates of 2- to 3-month-old mice as described previously (Leshchyns'ka et al., 2003).

Immunohistochemistry. Tissue preparation and immunohistochemistry on cerebella of young C57BL/6 mice was done as described previously (Jakovcevski et al., 2009).

Spinal cord injury. Three-month-old female mice were anesthetized by intraperitoneal injection of ketamine and xylazine [100 mg of Ketanest (Parke-Davis/Pfizer) and $5 \mathrm{mg}$ of Rompun (Bayer, Leverkusen, Germany) per kilogram of body weight]. Laminectomy was performed at the T7-T9 level with mouse laminectomy forceps (Fine Science Tools). A mouse spinal cord compression device was used for compression injury (Curtis et al., 1993). Compression force (degree of closure of the forceps) and duration were controlled by an electromagnetic device. The spinal cord was maximally compressed $[100 \%$, according to the operational definition of Curtis et al. (1993)] for $1 \mathrm{~s}$ by a time-controlled current flow through the electromagnetic device. The skin was then surgically closed using 6-0 nylon stitches (Ethicon). After surgery, mice were kept in a heated room $\left(35^{\circ} \mathrm{C}\right)$ for several hours to prevent hypothermia and then housed singly in a temperature-controlled $\left(22^{\circ} \mathrm{C}\right)$ room with water and standard food provided ad libitum. After the surgery, bladders of the animals were manually voided twice daily.

Histological analysis of the spinal cords. Mice were transcardially perfused with fixative consisting of $4 \%$ formaldehyde and $0.1 \% \mathrm{CaCl}_{2}$ in 0.1

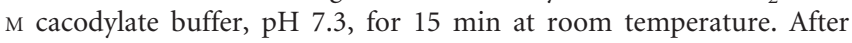
perfusion, the spinal cords were dissected out and postfixed overnight at $4^{\circ} \mathrm{C}$ in the same solution as used for perfusion and then cryoprotected in $15 \%$ sucrose solution in $0.1 \mathrm{M}$ cacodylate buffer, $\mathrm{pH} 7.3$, for $2 \mathrm{~d}$ at $4^{\circ} \mathrm{C}$. Pieces of spinal cords $1 \mathrm{~cm}$ in length centered at the lesion site were embedded in Tissue Tek (Sakura Finetek), and frozen by 2 min immersion into 2-methyl-butane (isopentane) precooled to $-80^{\circ} \mathrm{C}$. Serial longitudinal sections were cut in a cryostat (CM3050; Leica), and $25-\mu \mathrm{m}$-thick sections were collected on SuperFrost Plus glass slides (Roth). Spaced serial sections $250 \mu \mathrm{m}$ apart were stained with cresyl violet/luxol fast blue and used for estimations of the scar volume using the Cavalieri principle. Areas of the scar required for volume estimation were measured directly under the microscope using Neurolucida software (MicroBrightField). Immunofluorescence labeling of the spinal cord tissue with anti-5-HT and anti-TH antibodies was performed as described previously (Jakovcevski et al., 2007).

Analysis of locomotor function. The recovery of ground locomotion was evaluated using the Basso, Beattie, Bresnahan (BBB) rating scale (Basso et al., 1995) modified for mice (Joshi and Fehlings, 2002) and a novel singleframe motion analysis (Apostolova et al., 2006). This method includes evaluation of four parameters in three different tests: beam walking (foot-stepping angle and rump-weight index), voluntary movements 
without body weight support (extension-flexion ratio), and inclined ladder climbing (number of correct steps). Assessment was performed before and at 1,3, and 6 weeks after the injury. Values for the left and right legs were averaged.

\section{Results}

\section{Proteolysis of Caspr is enhanced in brains of} PrP-deficient mice

Since PrP is highly expressed in the developing brain and regulates neurite outgrowth (Graner et al., 2000; Lopes et al., 2005; Santuccione et al., 2005; Lima et al., 2007), we analyzed whether PrP deficiency is accompanied by changes in levels of adhesion molecules in brains of $\mathrm{PrP}$-deficient $\left(\mathrm{PrP}^{-1-}\right)$ versus wild-type $\left(\mathrm{PrP}^{+/+}\right)$mice. Western blot analysis with antibodies against the intracellular domain of Caspr showed that levels of full-length Caspr with the molecular weight of $\sim 180 \mathrm{kDa}$ were approximately twofold lower in $\mathrm{PrP}^{-1-}$ versus $\mathrm{PrP}^{+/+}$brain homogenates from adult mice (Fig. $1 \mathrm{~A}$ ). A reduction in full-length Caspr protein levels in $\mathrm{PrP}^{-/-}$brain homogenates was accompanied by an increase in levels of a degradation product of Caspr with the molecular weight of $\sim 50 \mathrm{kDa}$ (Fig. $1 A$ ). Since PrP, as a GPIanchored protein, accumulates in lipid rafts, we also analyzed Caspr levels in lipid rafts isolated from $\mathrm{PrP}^{+/+}$and $\mathrm{PrP}^{-1-}$ brains. Similar to the results with brain homogenates, levels of full-length Caspr were decreased while levels of the $50 \mathrm{kDa}$ degradation product of Caspr were increased in $\mathrm{PrP}^{-1-}$ versus $\mathrm{PrP}^{+/+}$lipid rafts from the brains of adult mice (Fig. $1 B$ ). Caspr degradation was also increased in the brains of young, 10-d-old $\mathrm{PrP}^{-/-}$mice when compared with young $\mathrm{PrP}^{+/+}$mice (Fig. 1C). In the young animals, however, intermediate degradation products of $\sim 100 \mathrm{kDa}$ were also present, but were increased in $\mathrm{PrP}^{-1-}$ brains (Fig. 1C). Thus, our observations indicate that $\operatorname{PrP}$ deficiency results in enhanced proteolytic processing of Caspr in developing and mature brains. In contrast, levels of the neural cell adhesion molecule NCAM were upregulated (Santuccione et al., 2005), while levels of the cell adhesion molecules contactin (Fig. 1) and L1 (data not shown) were not significantly affected by $\operatorname{PrP}$ deficiency.

\section{Caspr is a novel binding partner for PrP}

To analyze whether Caspr interacts with PrP, coimmunoprecipitation experiments were carried out. Caspr coimmunoprecipitated with PrP from lysates of adult (Fig. 2A) and young (Fig. 2C) mouse brains. Conversely, $\operatorname{PrP}$ coimmunoprecipitated with Caspr from lysates of young 10-d-old mouse brains (Fig. 2 B). These observations thus suggest that the two proteins interact with each other in the developing and mature brain. Contactin did not coimmunoprecipitate with $\operatorname{PrP}$ (Fig. 2A,C) and $\operatorname{PrP}$ did not coimmunoprecipitate with contactin (Fig. $2 C$ ), underscoring the specificity of the interaction of Caspr with PrP. This observation also suggests that $\mathrm{PrP}$ and contactin form two different complexes with Caspr. Binding of Caspr to contactin was stronger than that of Caspr to PrP, as shown by coimmunoprecipitation efficiency of these complexes from brain lysates of 10-d-old mice (Fig. $2 C$ ). While $\sim 11.6 \pm 1.57 \%$ of all Caspr molecules coimmunoprecipitated with contactin, $\sim 6.65 \pm 1.79 \%$ of all Caspr molecules coimmunoprecipitated with PrP.

Since coimmunoprecipitation experiments do not exclude the possibility that two proteins are linked by intermediate binding partners, we analyzed whether Caspr directly binds to PrP by ELISA. Indeed, Caspr purified from mouse brain bound to PrP-Fc in a concentration-dependent manner (Fig. $2 \mathrm{D})$. In contrast, Caspr did not bind to BSA or L1-Fc analyzed in parallel (Fig. 2D).
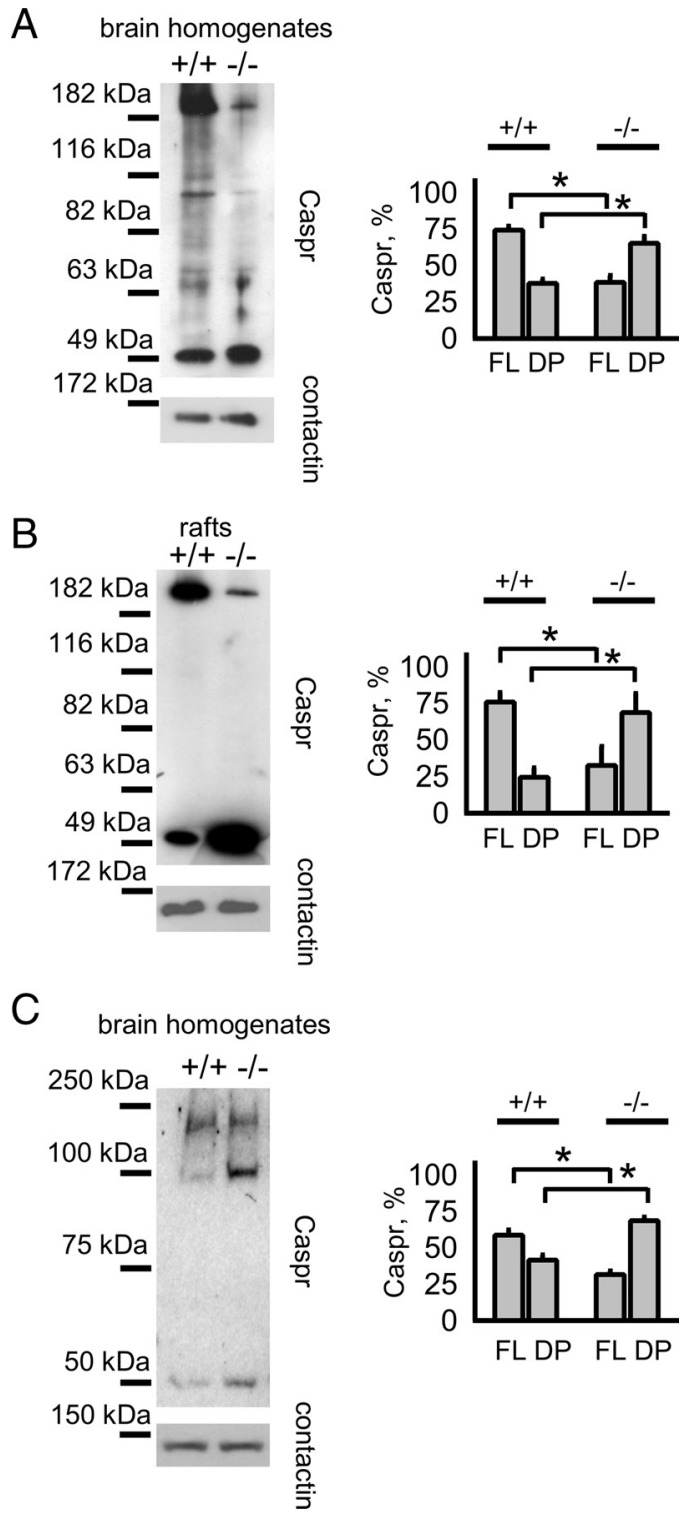

Figure 1. Proteolysis of Caspr is increased in $\operatorname{PrP}^{-/-}$brains. $A-C, \operatorname{PrP}^{+/+}$and $\operatorname{PrP}^{-1-}$ brain homogenates ( $\boldsymbol{A}$, adult animals; $\boldsymbol{C}$, young, 10-d-old animals) and lipid rafts ( $\boldsymbol{B}$, adult animals) were probed by Western blot with polyclonal antibodies against Caspr intracellular domain. Note that levels of the full-length $180 \mathrm{kDa}$ Caspr are reduced, while levels of the $50 \mathrm{kDa}$ degradation product of Caspr are increased in $\mathrm{PrP}^{-1-}$ brains and lipid rafts. In the brains of young animals, intermediate degradation products of $\sim 100 \mathrm{kDa}$ are also observed. Graphs show quantitation of the blots (mean \pm SEM, $n \geq 5$ ). Levels of full-length (FL) and a sum of degradation products (DP) of Caspr were normalized to the total Caspr level, defined as a sum of full-length and degradation product levels set to $100 \%$. Labeling for contactin served as a loading control. * $p<0.05$, paired $t$ test.

Indirect immunofluorescence labeling of early postnatal cerebellar neurons maintained in culture for $24 \mathrm{~h}$, i.e., the time of active neurite outgrowth, showed that PrP partially colocalized with Caspr along neurites, and both proteins were highly expressed in growth cones, where they also partially colocalized (Fig. 2 E). Furthermore, when Caspr was clustered at the cell surface with antibodies against the extracellular domain of Caspr applied to live neurons, $\operatorname{PrP}$ was partially redistributed to Caspr clusters (correlation coefficients between the distributions of $\operatorname{PrP}$ and Caspr were $0.25 \pm 0.02$ and $0.58 \pm 0.04$ for nonclustered and clustered Caspr, respectively) (Fig. $2 F, G$ ), suggesting that Caspr 
A

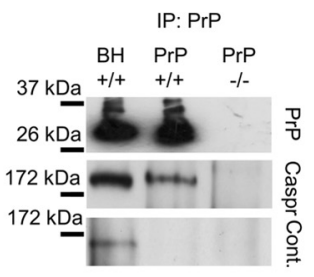

B
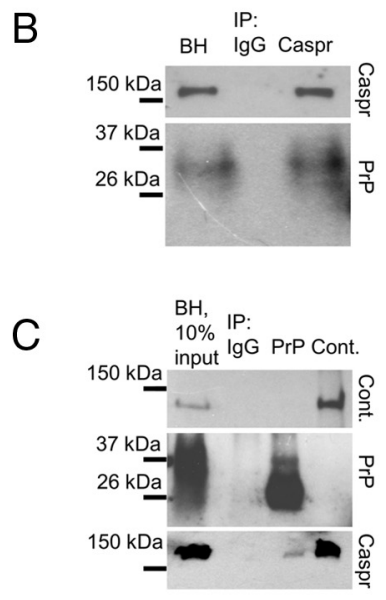

D

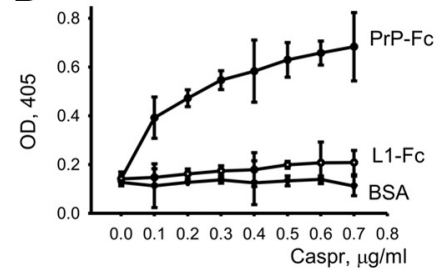

E

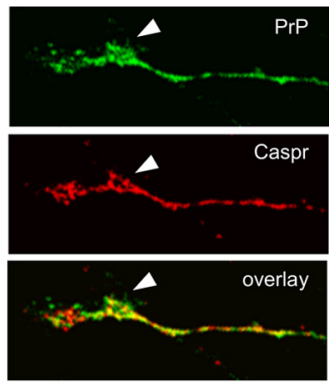

$\mathrm{F}$
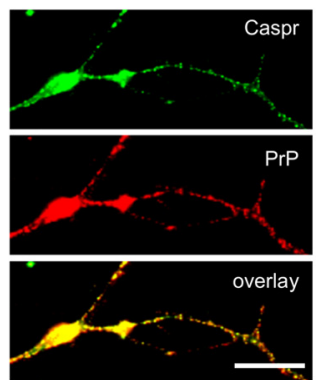

$\mathrm{G}$

Caspr Caspr PrP PrP tubulin tubulin

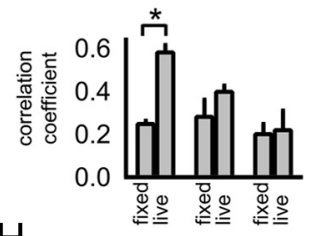

$\mathrm{H}$

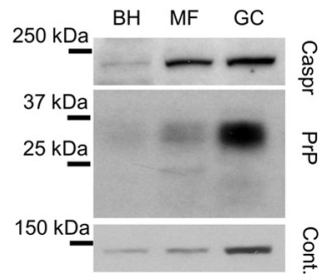

Figure 2. PrP directly interacts with Caspr. $A-C, \operatorname{PrP}^{+/+}$brain homogenate (BH) and immunoprecipitates (IP) with PrP, Caspr, or contactin (Cont.) antibodies prepared using PrP ${ }^{+/+}$ brain lysate were analyzed by Western blot with antibodies against PrP, the intracellular domain of Caspr, and contactin. Note that Caspr coimmunoprecipitates with PrP and contactin, but contactin and PrP do not coimmunoprecipitate with each other. Mock immunoprecipitation from $\operatorname{PrP}^{-1-}$ brain lysate $(A)$ or with nonspecific $\operatorname{lgs}(\lg G)(B, C)$ was performed to control for IP specificity. D, PrP-Fc, L1- $\mathrm{Fc}$, or BSA was immobilized on a plastic surface and assayed for its ability to bind increasing concentrations of Caspr purified from adult mouse brain. Mean values of optical density (OD) \pm SEM are shown. PrP-Fc, but not L1-Fc or BSA, bound to Caspr in a concentration-dependent manner. $\boldsymbol{E}, \boldsymbol{F}$, Cultured cerebellar neurons were fixed with $4 \%$ paraformaldehyde and labeled with antibodies against PrP and Caspr extracellular domain (E). Alternatively, these antibodies were applied together to live neurons to cluster Caspr and PrP, and then neurons were fixed $(\boldsymbol{F})$. Representative neurites are shown. Note that PrP and Caspr partially colocalize with each other along neurites, and both proteins accumulate in growth cones ( $\boldsymbol{E}$, arrowheads). Note also that clustering of proteins induces redistribution of Caspr and PrP to overlapping clusters, suggesting that they are associated. Scale bar, $10 \mu \mathrm{m}$. G, Graph shows correlation coefficients (mean \pm SEM) between the distributions of PrP, Caspr, and tubulin, which were labeled in fixed neurons or in neurons incubated live with Caspr and PrP antibodies to cluster these proteins. ${ }^{*} p<0.05, t$ test. $\boldsymbol{H}$, Brain homogenates (BH), total membrane fractions (MF), and growth cones (GC) were probed by Western blot with antibodies against Caspr, PrP and contactin. Note that all three proteins accumulate in the growth cone fraction.

associates with $\operatorname{PrP}$ at the cell surface. In contrast, clustering of Caspr did not induce redistribution of tubulin (Fig. $2 G$ ).

In support of our immunocytochemical data, Caspr and $\operatorname{PrP}$ were enriched in the growth cone fraction when compared with

total membrane fraction or total brain homogenates prepared from young mouse brains (Fig. $2 \mathrm{H}$ ). Similarly, contactin was also enriched in growth cones (Fig. $2 H$ ).

\section{PrP inhibits shedding of Caspr from the cell surface}

The molecular weight of the intracellular domain of Caspr is $\sim 10$ $\mathrm{kDa}$. Hence, the cleavage product of $\sim 50 \mathrm{kDa}$ recognized by antibodies against the C-terminal part of the Caspr intracellular domain should include the whole intracellular and transmembrane domains and the cell surface membrane-adjacent portions of Caspr. The occurrence of this degradation product, therefore, suggested that the extracellular domain of Caspr should be released from the cell surface. To verify this idea, we analyzed Caspr $^{+/+}$and Caspr $^{-1-}$ brain homogenates by Western blot with polyclonal antibodies against a peptide at the $\mathrm{N}$ terminus of Caspr. Labeling with these antibodies revealed a degradation product of Caspr with the molecular weight of $\sim 50 \mathrm{kDa}$ also (Fig. $3 A$ ). Since a single degradation product of $\sim 50 \mathrm{kDa}$ could not contain two epitopes located at opposite parts of the $190 \mathrm{kDa}$ full-length Caspr protein, the only explanation for this observation is that processing of Caspr includes its cleavage at several sites (at least two) within its extracellular domain. Such cleavage could then result in the release of Caspr fragments with molecular weights of $\sim 50 \mathrm{kDa}$. The occurrence of intermediate $100 \mathrm{kDa}$ cleavage products (Fig. 1C) further supports this idea.

Cleavage of cell surface-expressed Caspr within its extracellular domain should result in the release of extracellular domain fragments to the extracellular space, resulting in the shedding of Caspr from the cell surface. To verify that this occurs, medium from cultured cerebellar neurons was analyzed by Western blot with polyclonal antibodies against the $\mathrm{N}$ terminus of Caspr. Indeed, the culture medium from Caspr ${ }^{+/+}$neurons contained a Caspr degradation product with the molecular weight of $\sim 50$ $\mathrm{kDa}$ that was recognized by antibodies against the $\mathrm{N}$ terminus of Caspr (Fig. 3B). This degradation product was not present in the culture medium from $\mathrm{Caspr}^{-1-}$ neurons (Fig. $3 B$ ), indicating the specificity of the labeling. Importantly, levels of the Caspr degradation product were increased in the culture medium from $\mathrm{PrP}^{-/-}$versus $\mathrm{PrP}^{+/+}$neurons (Fig. 3B). Furthermore, levels of Caspr were reduced at the cell surface of $\mathrm{PrP}^{-/-}$versus $\mathrm{PrP}^{+/+}$ neurons that were labeled by indirect immunofluorescence with polyclonal antibodies against epitopes in the extracellular domain of Caspr (mean levels \pm SEM of surface Caspr along neurites were $139.9 \pm 9.5$ and $80 \pm 8.6$ arbitrary units in $\operatorname{PrP}^{+1+}$ and $\mathrm{PrP}^{-1-}$ neurites, respectively; arbitrary units were defined as pixel values from the gray scale fluorescence images used for quantitation; ${ }^{*} p<0.05, t$ test) (Fig. $3 C$ ). In contrast, levels of $\mathrm{L} 1$ at the neuronal cell surface were similar in $\mathrm{PrP}^{+/+}$and $\mathrm{PrP}^{-1-}$ neurons (mean levels \pm SEM of L1 were $126.8 \pm 4.2$ and $127.9 \pm$ 3.8 arbitrary units in $\mathrm{PrP}^{+/+}$and $\mathrm{PrP}^{-1-}$ neurons, respectively; $p>0.05, t$ test).

To verify the role of PrP in inhibiting shedding of Caspr from the cell surface, we transfected $\mathrm{CHO}$ cells, which do not express Caspr or PrP, with cDNAs encoding these proteins. For comparison, $\mathrm{CHO}$ cells were also transfected with contactin, which has been shown to enhance Caspr levels at the cell surface (FaivreSarrailh et al., 2000). Cell surface proteins in transfected cells were then biotinylated and separated from the total protein pool using streptavidin-agarose. Western blot analysis of the total and biotinylated protein fractions with polyclonal antibodies against the intracellular domain of Caspr showed that levels of Caspr at the cell surface were approximately threefold higher in cells cotransfected with Caspr and PrP versus cells transfected with 

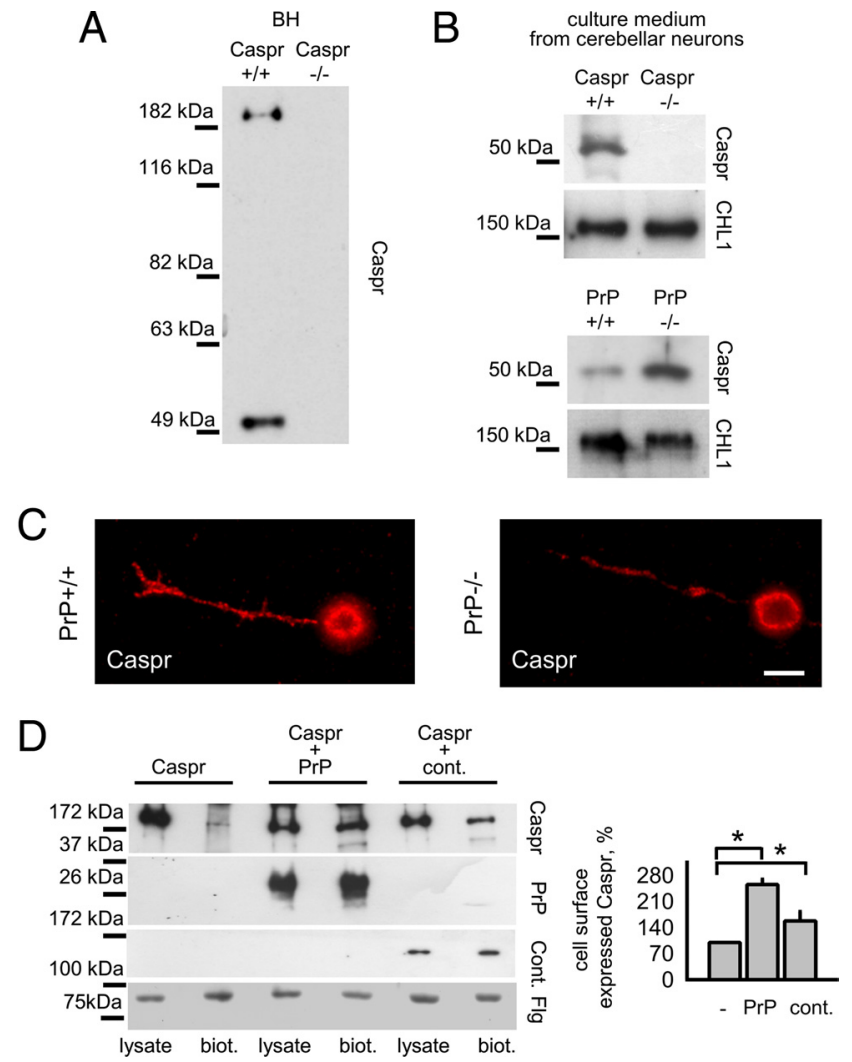

Figure 3. PrP increases cell surface expression of Caspr. $A$, Caspr ${ }^{+/+}$and Caspr ${ }^{-/-}$brain homogenates were probed by Western blot with polyclonal antibodies (N15) against a peptide at the $\mathrm{N}$ terminus of Caspr extracellular domain. Note that the full-length $180 \mathrm{kDa}$ product and the $50 \mathrm{kDa}$ degradation product of Caspr are recognized in $\mathrm{Caspr}^{+/+}$but not in $\mathrm{Caspr}^{-1-}$ brain homogenates. $\boldsymbol{B}$, Culture medium from $\mathrm{Caspr}^{+/+}$and $\mathrm{Caspr}^{-/-}$(top) or $\mathrm{PrP}^{+/+}$and $\mathrm{PrP}^{-1-}$ (bottom) cerebellar neurons was analyzed by Western blot with polyclonal antibodies against Caspr extracellular domain. Note that these antibodies recognize the $50 \mathrm{kDa}$ degradation product of Caspr in the culture medium from $\mathrm{Caspr}^{+/+}$but not Caspr ${ }^{-/-}$neurons. The level of this band is increased in the culture medium from $\operatorname{PrP}^{-1-}$ versus $\operatorname{PrP}^{+/+}$neurons. Labeling for close homolog of $\mathrm{L}$ (CHL1), which is also released into the culture medium, served as a loading control. C, Cultured $\mathrm{PrP}^{+/+}$and $\mathrm{PrP}^{-/-}$cerebellar neurons were labeled live with polyclonal antibodies against Caspr extracellular domain. Note reduced levels of Caspr at the cell surface of PrP ${ }^{-1-}$ versus PrP $^{+1+}$ neurites. Scale bar, $10 \mu \mathrm{m}$. D, CHO cells were transfected with Caspr alone or cotransfected with Caspr and PrP or contactin (cont.). Cell surface proteins were then biotinylated on live cells and separated via streptavidin-coated beads from the total protein pool following cell lysis. Samples containing cell surface proteins (biot.) and total cell lysates (lysate) were then probed by Western blot with polyclonal antibodies against Caspr intracellular domain, PrP, and contactin. Labeling for the FGF receptor (Flg) served as a loading control. Higher levels of cell surface-biotinylated Caspr are observed in the samples of cells cotransfected with Caspr and PrP when compared with Caspr-only transfected cells. Cell surface Caspr levels are also higher in contactin and Caspr cotransfected versus Caspr-only transfected cells, although this effect is less prominent than in Caspr and PrP cotransfected cells. Graph shows quantitation of the blots (mean $\pm \mathrm{SEM}, n=3$ ) with the signal from Caspr-only transfected cells set to $100 \% .{ }^{*} p<0.05$, paired $t$ test.

Caspr alone (Fig. 3D). Interestingly, cotransfection with PrP promoted accumulation of Caspr at the cell surface to even higher levels than cotransfection of Caspr with contactin (Fig. 3D). Altogether, our data indicate that the cleavage of Caspr occurs at the cell surface, resulting in shedding of Caspr, and that this process is regulated by $\mathrm{PrP}$, which inhibits the proteolytic cleavage of Caspr.

\section{PrP inhibits serine protease-mediated proteolysis of Caspr at} the cell surface

To identify the proteases that are involved in shedding of Caspr from the cell surface, we assayed the release of the $50 \mathrm{kDa}$ frag-

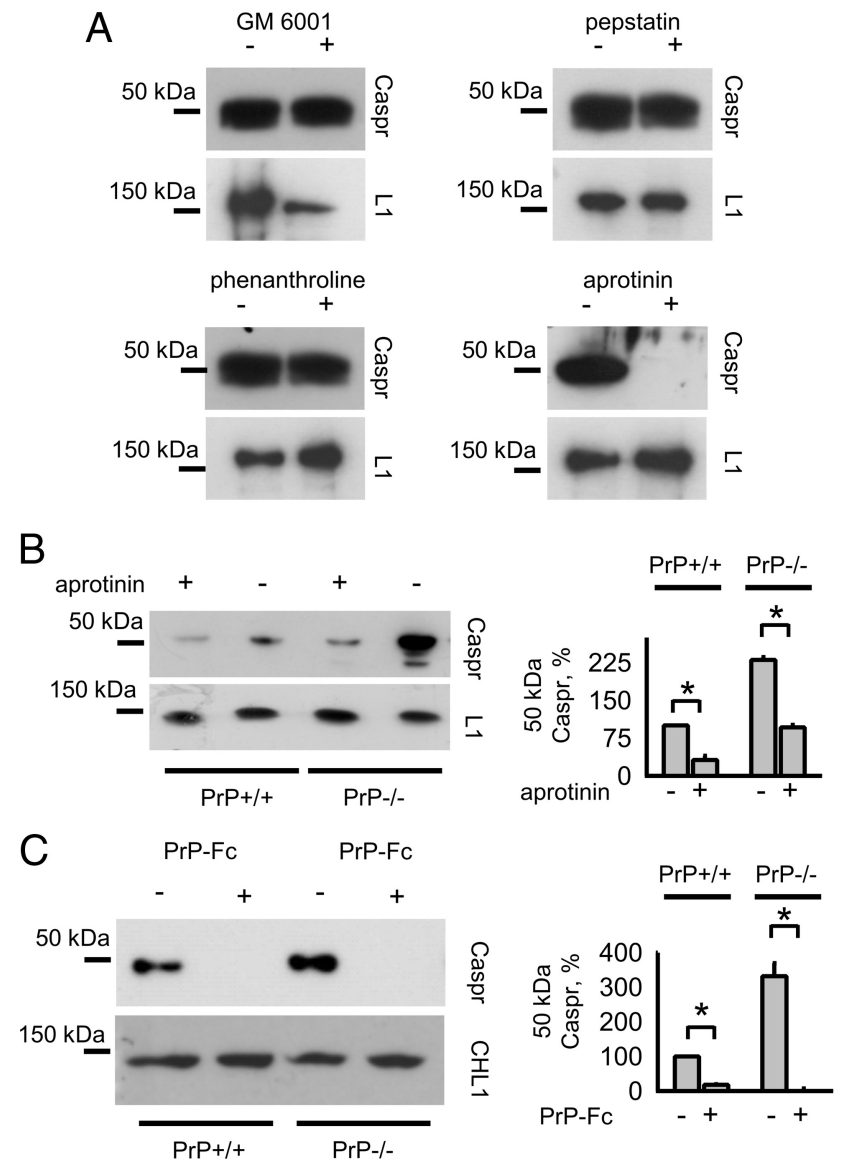

Figure 4. PrP inhibits serine protease-mediated proteolysis of Caspr at the cell surface. A, Culture medium collected from $\mathrm{PrP}^{-1-}$ cerebellar neurons nontreated or treated with inhibitors of matrix metalloproteases (GM6001 or phenanthroline), aspartic proteases (pepstatin), or serine proteases (aprotinin) was analyzed by Western blot with polyclonal antibodies against the extracellular domain of Caspr. Only aprotinin decreases levels of the $50 \mathrm{kDa}$ degradation product of Caspr in the culture medium. Labeling for L1 served as a loading control. $B$, Culture medium collected from $\mathrm{PrP}^{+/+}$and $\mathrm{PrP}^{-1-}$ cerebellar neurons nontreated or treated with aprotinin was analyzed by Western blot with polyclonal antibodies against the extracellular domain of Caspr. Labeling for L1 served as a loading control. Note that aprotinin reduces levels of the $50 \mathrm{kDa}$ Caspr degradation product in $\mathrm{PrP}^{+/+}$and $\mathrm{PrP}^{-/-}$neurons. Graph shows quantitation of the blots (mean \pm SEM, $n=3$ ) with the signal from nontreated $\operatorname{PrP}+/+$ neurons set to $100 \%{ }^{*} p<0.05$, paired $t$ test. C, Culture medium collected from $\mathrm{PrP}^{+/+}$or $\mathrm{PrP}^{-1-}$ cerebellar neurons nontreated or treated with PrP-Fc was analyzed by Western blot with polyclonal antibodies against Caspr extracellular domain. Labeling for $L 1$ served as a loading control. Note that PrP-Fc application reduces levels of the $50 \mathrm{kDa}$ degradation product of Caspr in the culture medium.

ment from cultured cerebellar neurons treated with inhibitors of different classes of proteases. Western blot analysis of culture supernatants with polyclonal antibodies against the extracellular domain of Caspr showed that inhibitors of the matrix metalloproteases GM6001 and phenanthroline and the inhibitor of aspartic proteases pepstatin had no effect on the shedding of Caspr. In contrast, the inhibitor of serine proteases, aprotinin, strongly inhibited the release of the $50 \mathrm{kDa}$ fragment of Caspr into the culture medium (Fig. 4A). Caspr shedding was inhibited by aprotinin in cultures of $\operatorname{PrP}^{+/+}$and $\operatorname{PrP}^{-1-}$ neurons (Fig. 4B). To investigate whether PrP inhibits the activity of a serine protease that cleaves Caspr at the cell surface, we treated $\mathrm{PrP}^{+/+}$and $\mathrm{PrP}^{-1-}$ neurons with PrP-Fc applied in the culture medium. Similar to aprotinin, PrP-Fc strongly inhibited the release of the $50 \mathrm{kDa}$ fragment to the culture medium (Fig. 4C). 
A

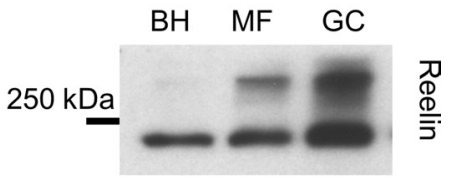

B

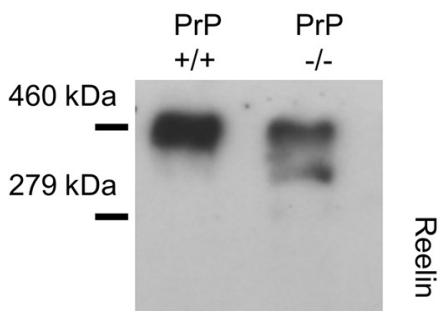

$150 \mathrm{kDa}$

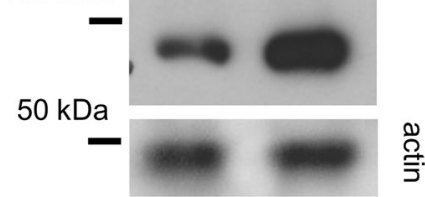

C

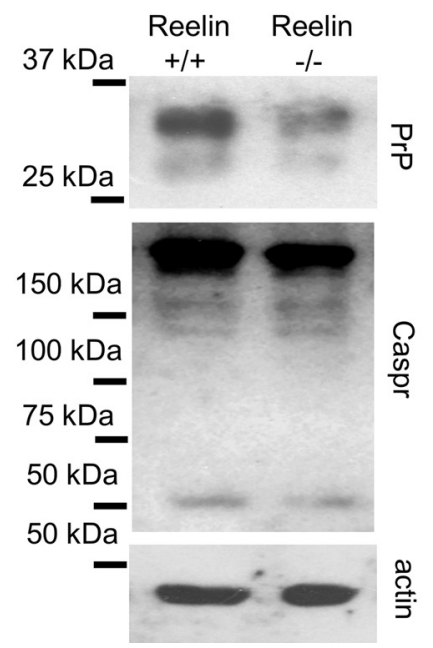

Figure 5. Reelin accumulates in growth cones, and levels of its active form are increased in $\mathrm{PrP}^{-1-}$ brains. A, Brain homogenates (BH), total membrane fractions (MF), and growth cones $(\mathrm{GC})$ were probed by Western blot with antibodies against Reelin. Note that Reelin accumulates in the growth cone fraction. $B, \mathrm{PrP}^{+/+}$and $\mathrm{PrP}^{-/-}$brain homogenates were probed by Western blot with antibodies against Reelin. Note decreased levels of the full-length $400 \mathrm{kDa}$ Reelin and increased levels of the $140 \mathrm{kDa}$ form of Reelin in $\mathrm{PrP}^{-1-}$ versus $\mathrm{PrP}^{+/+}$brain homogenates. Actin served as a loading control. C, Reelin ${ }^{+/+}$and Reelin ${ }^{-/-}$brain homogenates were probed by Western blot with antibodies against PrP and Caspr. Note decreased levels of PrP in Reelin ${ }^{-/-}$versus Reelin ${ }^{+/+}$brain homogenates. Actin served as a loading control.

\section{Reelin is involved in Caspr proteolysis}

Reelin, an extracellular matrix glycoprotein and serine protease, is highly expressed during brain development (Rice and Curran, 2001; Tissir and Goffinet, 2003), and its proteolytic activity is inhibited by aprotinin (Quattrocchi et al., 2002). Interestingly, Reelin cleaves its substrates, such as fibronectin or laminin, at several sites releasing several smaller fragments (Quattrocchi et al., 2002), making it a plausible candidate for cleavage of Caspr, which also contains laminin-like domains in its structure. Western blot analysis with Reelin antibodies showed that Reelin accumulates in the growth cone fraction (Fig. 5A), which is also enriched in Caspr and $\operatorname{PrP}$ (Fig. $2 \mathrm{H}$ ). The levels of the full-length Reelin with the molecular weight of $\sim 400 \mathrm{kDa}$ were decreased in $\mathrm{PrP}^{-/-}$versus $\mathrm{PrP}^{+/+}$brain homogenates (Fig. 5B). A decrease in the levels of full-length Reelin was accompanied by an increase in the levels of its autoproteolytic degradation product with the molecular weight of $\sim 140 \mathrm{kDa}$ by $93 \pm 32 \%\left({ }^{\star} p<0.05, n=3\right.$, paired $t$ test) in $\operatorname{PrP}^{-1-}$ brain homogenates (Fig. $5 B$ ). This degradation product of Reelin possesses higher proteolytic activity than the full-length Reelin (Quattrocchi et al., 2002). These observations suggest that the proteolytic activity of Reelin is increased in $\mathrm{PrP}^{-1-}$ versus $\operatorname{PrP}^{+/+}$brains.

To analyze the role of Reelin in Caspr cleavage, we compared Caspr levels in Reelin-deficient (Reelin ${ }^{-1-}$ ) and wild-type (Ree$\operatorname{lin}^{+/+}$) mice. Western blot analysis of the brain homogenates showed that production of the $50 \mathrm{kDa}$ Caspr fragment was not significantly reduced in Reelin ${ }^{-1-}$ versus Reelin ${ }^{+/+}$brains $(16.97 \pm 2.45 \%$ versus $19.24 \pm 2.4 \%$ of the total Caspr level in Reelin $^{-/-}$and Reelin ${ }^{+/+}$mice, respectively) (Fig. 5C). Remarkably, levels of PrP were reduced by $46.7 \pm 3.4 \%\left({ }^{*} p<0.05, n=3\right.$, paired $t$ test) in Reelin ${ }^{-/-}$versus Reelin ${ }^{+/+}$mice (Fig. $5 C$ ), further suggesting a relationship between Reelin and PrP. Since reduced expression of $\mathrm{PrP}$ is associated with Caspr proteolysis (Fig. $1 A-C)$, this may explain the relatively mild effect of Reelin deficiency on Caspr degradation, suggesting that under conditions of reduced PrP expression Caspr is cleaved by other proteases in Reelin ${ }^{-1-}$ brains.

To analyze the effect of Reelin on Caspr levels in a more direct manner, we transfected $\mathrm{CHO}$ cells with Caspr alone or cotransfected them with Caspr together with Reelin or PrP. Western blot analysis of $\mathrm{CHO}$ cell lysates showed that levels of full-length Caspr were increased in cells cotransfected with Caspr and PrP versus cells transfected with Caspr alone (Fig. 6A). This observation is in accordance with our results in $\operatorname{PrP}^{+/+}$and $\operatorname{PrP}^{-1-}$ brain homogenates (Fig. 1). In $\mathrm{CHO}$ cells cotransfected with Caspr and Reelin, levels of full-length Caspr were drastically reduced (Fig. 6A), being accompanied by an increase in levels of the extracellular $50 \mathrm{kDa}$ Caspr fragment in cell lysates and culture medium, further suggesting that Reelin is involved in proteolysis of Caspr at the cell surface. In contrast, Reelin-mediated Caspr proteolysis was inhibited in $\mathrm{CHO}$ cells cotransfected with Caspr together with Reelin and PrP (Fig. 6A), indicating that PrP inhibits Reelin-mediated proteolysis of Caspr.

Unlike PrP, contactin did not inhibit Caspr proteolysis in transfected CHO cells. On the contrary, full-length Caspr levels were reduced in $\mathrm{CHO}$ cells cotransfected with contactin (Fig. $6 \mathrm{~B})$. Caspr proteolysis was further enhanced in cells overexpressing contactin together with Reelin (Fig. $6 \mathrm{~B}$ ). A plausible explanation for this observation is that contactin-mediated delivery of Caspr to the cell surface (Fig. 3D) results in exposure of Caspr to extracellular proteases, such as Reelin, followed by Caspr degradation in the absence of protective, i.e., degradation-preventing, PrP.

In accordance with our data from transfected $\mathrm{CHO}$ cells, incubation of the recombinant extracellular domain of Caspr fused to human $\mathrm{Fc}(\mathrm{Caspr}-\mathrm{Fc})$ with recombinant Reelin also resulted in a reduction in levels of full-length Caspr-Fc (Fig. 6C). A reduction in full-length Caspr-Fc levels was accompanied by an increase in levels of its $50 \mathrm{kDa}$ degradation product in the probes incubated with Reelin (Fig. 6C). A similar effect was observed when Caspr purified from mouse brain was incubated with recombinant Reelin (data not shown). Reelin, however, did not have any effect on levels of L1 analyzed in parallel (Fig. 6C).

Finally, we analyzed whether Caspr, PrP, and Reelin colocalize in the brain by immunohistochemically analyzing brain sections from 10-d-old wild-type mice. All three proteins were highly expressed in the cerebellum (Fig. 7). Colabeling with the antibodies 
A

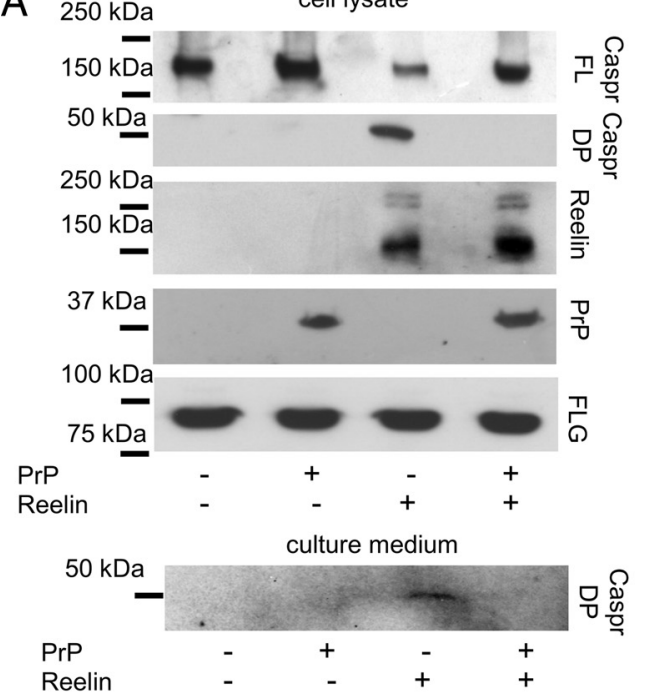

B
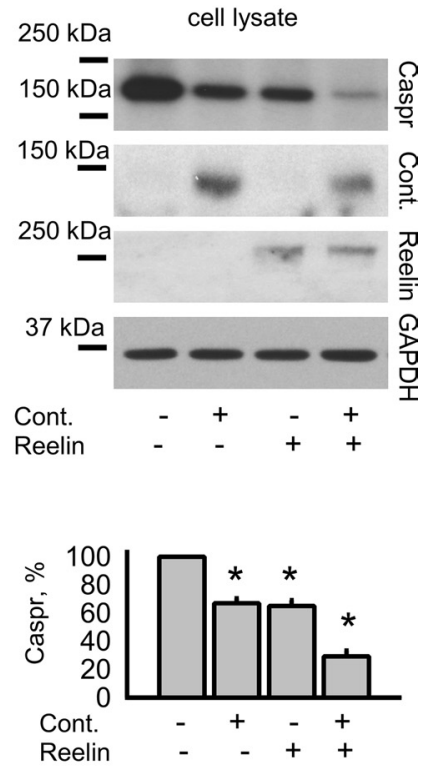

C $250 \mathrm{kDa}$
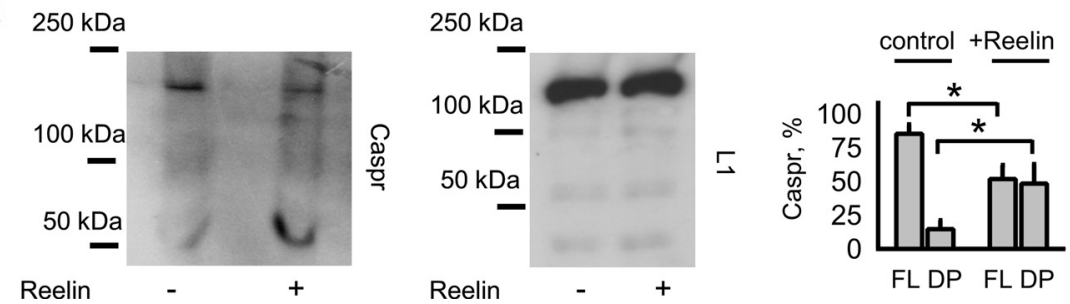

Figure 6. PrP but not contactin inhibits Reelin-mediated Caspr proteolysis. A, CHO cells were transfected with Caspr alone, or cotransfected with Caspr and PrP or Reelin as indicated. Cell lysates were then analyzed with antibodies against Reelin, PrP, Caspr intracellular domain, and FGFR1 (FLG) as a loading control. Culture medium was analyzed with antibodies against the extracellular domain of Caspr. Note that levels of full-length Caspr are reduced in cells cotransfected with Caspr and Reelin and that this effect is blocked in cells cotransfected with Caspr, Reelin, and PrP. Cotransfection with Reelin results in the appearance of the $50 \mathrm{kDa}$ degradation product of Caspr in lysates and culture medium. $\boldsymbol{B}$, CHO cells were transfected with Caspr alone or cotransfected with Caspr and contactin (Cont.) or Reelin as indicated. Cell lysates were then analyzed with antibodies against Reelin, contactin, Caspr intracellular domain, and GAPDH as a loading control. Note that Caspr proteolysis is enhanced in cells cotransfected with contactin. Graph shows quantitation of the blots (mean \pm SEM, $n=6$ ). Full-length Caspr levels in cells transfected with Caspr without contactin and Reelin were set to $100 \% .{ }^{*} p<0.05$, paired $t$ test. C, Caspr-Fc and L1 from mouse brain were incubated with Reelin-containing culture medium from $\mathrm{CHO}$ cells transfected with full-length Reelin or medium from CHO cells transfected with pcDNA3 for control. Proteins were then probed by Western blot with polyclonal antibodies against the extracellular domain of Caspr or L1, respectively. Note that levels of full-length Caspr are reduced whereas levels of $50 \mathrm{kDa}$ degradation product of Caspr are increased following preincubation with Reelin. Reelin does not influence L1 levels. Graph shows quantitation of the blots (mean \pm SEM, $n=$ 3). Levels of full-length (FL) and $50 \mathrm{kDa}$ degradation product (DP) of Caspr were normalized to the total Caspr level defined as a sum of full-length and $50 \mathrm{kDa}$ degradation product levels set to $100 \% .{ }^{*} p<0.05$, paired $t$ test.

to calbindin, a marker of Purkinje cells, showed that Caspr is highly expressed in this cell type (Fig. 7A). At slightly lower levels than in Purkinje cells, Caspr was also present in the molecular and granular layers of the cerebellum (Fig. $7 A, B$ ). PrP and Reelin were also expressed in the molecular and granular layers of the cerebellum but were undetectable in Purkinje cells (Fig. 7A). Colabeling with antibodies against Caspr and Reelin showed that the distributions of the two proteins highly overlapped in the molecular and granular layers of the cerebellum (Fig. 7B). Similarly, Caspr distribution highly overlapped with the distribution of PrP in the molecular and granular layers (Fig. 7B). In summary, our observations suggest that functional interactions between Caspr, PrP, and Reelin also take place in vivo.

\section{Caspr inhibits neurite outgrowth of cerebellar neurons}

While Caspr is highly expressed in growing cerebellar (Figs. 2C,D, $3 C, 7)$ and hippocampal neurons (data not shown), its functional role in neurite outgrowth remains poorly understood. High levels of Caspr in growth cones of neurites suggest that Caspr may play a role in the regulation of neurite outgrowth. To analyze this possibility, we compared neurite outgrowth from cerebellar neurons of $\mathrm{Caspr}^{+/+}$and $\mathrm{Caspr}^{-1-}$ mice maintained on glass coverslips coated with poly-L-lysine alone or in combination with laminin or PrP-Fc. Strikingly, $24 \mathrm{~h}$ after plating, neurites of $\mathrm{Caspr}^{-\prime-}$ neurons were longer than those of $\mathrm{Caspr}^{+/+}$neurons on all substrates tested (Fig. $8 \mathrm{~A}$ ), suggesting that interactions of Caspr at the neuronal cell surface with substrate-coated poly-L-lysine, which may also attract molecules released from the cultured cells or present in the culture medium, inhibit neurite outgrowth. This effect was not compensated by outgrowth-promoting agents such as laminin or PrP-Fc. To confirm this, we maintained Caspr ${ }^{+/+}$neurons on glass coverslips coated with poly-Llysine alone or in combination with three different polyclonal antibodies against different epitopes in the extracellular domain of Caspr. These antibodies reduced neurite outgrowth compared with neurite outgrowth on poly-L-lysine alone (Fig. $8 B)$. One possible explanation of this result is that Caspr antibodies protect Caspr from cleavage. However, levels of fulllength Caspr were similar in cultures treated with Caspr antibodies or control nonspecific Igs (Fig. 8C). Therefore, our results suggest that binding of Caspr to extracellular ligands, such as substrate-coated antibodies, inhibits neurite outgrowth by triggering intracellular signaling events. Again, antibodies against the extracellular domain of Caspr inhibited neurite outgrowth even in the presence of the outgrowth promoting agents, such as laminin or PrP-Fc (Fig. 8D). Neurite outgrowth from $\mathrm{Caspr}^{-/-}$neurons analyzed for control was not affected by polyclonal antibodies against the extracellular domain of Caspr (Fig. 8D), showing the specificity of the effect exerted by the antibodies.

\section{PrP deficiency attenuates the inhibitory effect of Caspr on neurite outgrowth}

Since PrP deficiency results in reduced levels of Caspr at the neuronal surface, we compared neurite outgrowth from $\mathrm{PrP}^{+/+}$and $\mathrm{PrP}^{-l-}$ cerebellar neurons in vitro. Similar to $\mathrm{Caspr}^{-/-}$neurons, $\mathrm{PrP}^{-1-}$ neurons extended neurites better than $\mathrm{PrP}^{+/+}$neurons independently of whether neurons were grown on poly-L-lysine alone or in combination with laminin or PrP-Fc (Fig. 9A). Addition of aprotinin to the culture medium, however, negated this difference (Fig. 9A). In view of our results on shedding of Caspr from the neuronal cell surface, a plausible explanation for this observation could be that increased Caspr shedding from $\mathrm{PrP}^{-1-}$ neurons relieves Caspr-mediated inhibition of neurite outgrowth, 
while aprotinin-mediated inhibition of Caspr shedding negates the difference between $\mathrm{PrP}^{+/+}$and $\mathrm{PrP}^{-/-}$neurons.

To investigate this idea, we compared the effects of Caspr on neurite outgrowth from $\mathrm{PrP}^{+/+}$and $\mathrm{PrP}^{-1-}$ neurons. Indeed, while neurite outgrowth from $\mathrm{PrP}^{+/+}$neurons grown on poly-L-lysine in combination with the antibodies against the extracellular domain of Caspr was reduced when compared with $\mathrm{PrP}^{+/+}$ neurons grown on poly-L-lysine alone, Caspr antibodies had little effect on neurite outgrowth from $\mathrm{PrP}^{-1-}$ neurons (Fig. 9B). Similarly, polyclonal antibodies against the extracellular domain of Caspr had no effect on neurite outgrowth from $\mathrm{PrP}^{-1-}$ neurons maintained on poly-Llysine together with laminin, but they inhibited neurite outgrowth from $\mathrm{PrP}^{+/+}$ neurons maintained on this substrate (Fig. 9B). Antibodies against the intracellular domain of Caspr analyzed for control did not influence neurite outgrowth from $\mathrm{PrP}^{+/+}$neurons, indicating the specificity of the observed effects (Fig. 9B). The combined observations show that PrP deficiency results in reduced responsiveness of neurons to Caspr ligands, such as antibodies, correlating with reduced levels of Caspr at the surface of $\mathrm{PrP}^{-1-}$ neurons.

Finally, we analyzed the responsiveness of neurons to recombinant Reelin applied in the culture medium. Reelin produced by transiently transfected $\mathrm{CHO}$ cells, but not conditioned medium from mock-transfected control CHO cells, increased neurite outgrowth in wild-type neurons to the level of Caspr ${ }^{-1-}$ neurons (Fig. 9C). Reelin, however, did not promote neurite outgrowth in $\mathrm{Caspr}^{-1-}$ neurons (Fig. 9C). Hence, Caspr shedding is the most likely mechanisms by which Reelin promotes neurite outgrowth in wild-type neurons. Interestingly, Reelin induced an even stronger effect in $\mathrm{PrP}^{-1-}$ neurons (Fig. 9C), suggesting that the effect of recombinant Reelin is superimposed on the effect of endogenous Reelin, showing higher activity in $\mathrm{PrP}^{-1-}$ brains.

Increased Caspr proteolysis correlates with increased locomotor recovery after spinal cord injury in $\mathrm{PrP}^{-1-}$ versus $\operatorname{PrP}^{+/+}$mice

To analyze whether enhanced Caspr proteolysis correlates with increased axonal outgrowth in vivo, we compared the behavior of axons in spinal cords regenerating after thoracic compression lesions in $\mathrm{PrP}^{-1-}$ mice and their $\mathrm{PrP}^{+/+}$littermates. Immunohistochemical analysis showed that in lesioned spinal cords of $\mathrm{PrP}^{+/+}$mice, $\mathrm{PrP}$ was broadly distributed at the lesion site and rostrally to the lesion site (Fig. 10). Double labeling for PrP and Caspr showed that both molecules colocalized at the paranodal cation; in $\boldsymbol{B}$ ).
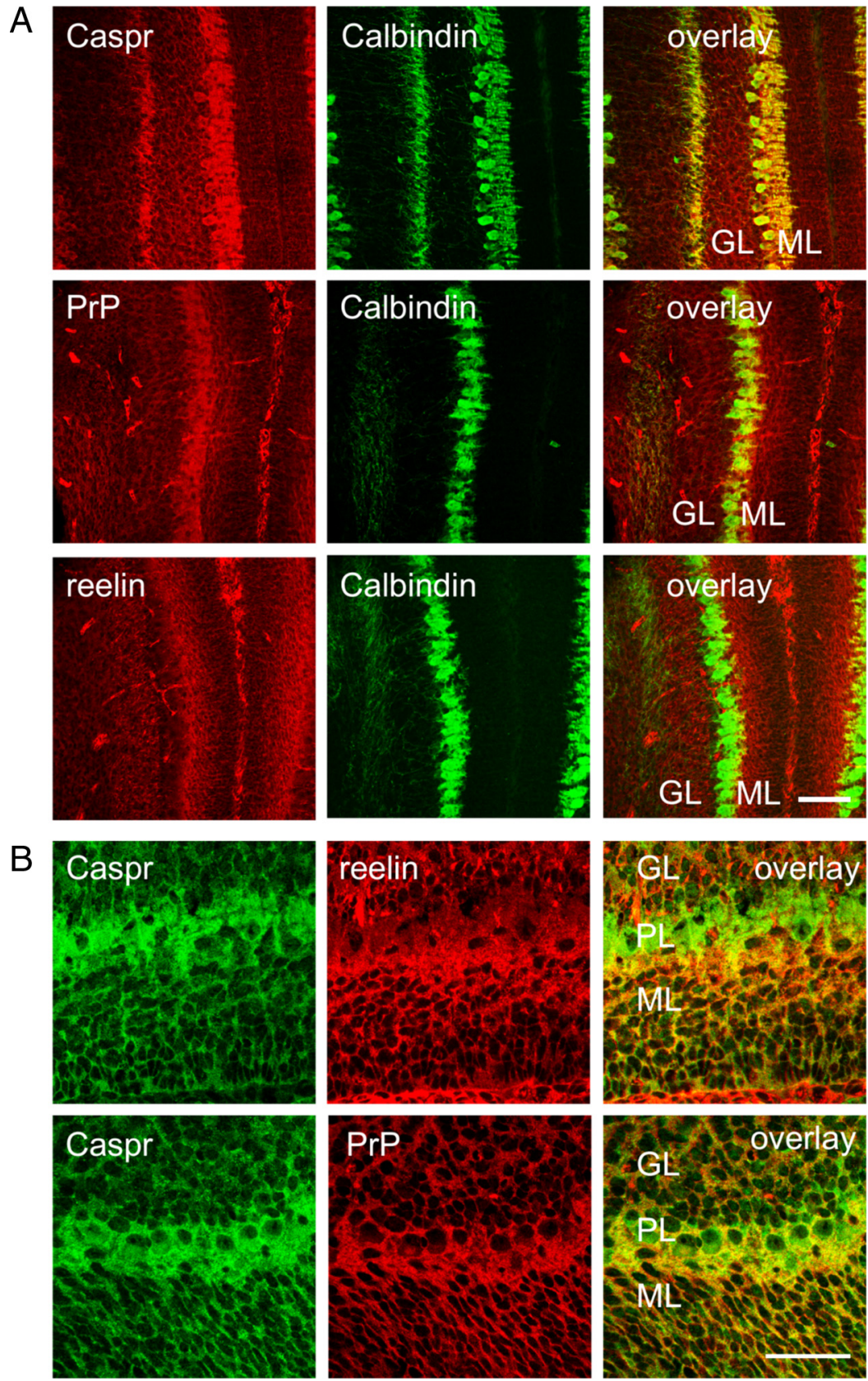

Figure 7. Caspr colocalizes with PrP and Reelin in the 10-d-old mouse cerebellum by immunohistochemistry. $A, B, \operatorname{Low}(\boldsymbol{A})$ and high $(\boldsymbol{B})$ magnification images of the mouse cerebellum labeled with antibodies against Caspr, PrP, Reelin, and calbindin are shown. Note, that Caspr is highly expressed in calbindin-positive Purkinje cells. Note also that Caspr colocalizes with PrP and Reelin in the granular (GL) and molecular (ML) layers of the cerebellum. Bar, $100 \mu \mathrm{m}$ (low magnification; in $A$ ), $40 \mu \mathrm{m}$ (high magnifi-

regions in the white matter of the injured $\mathrm{PrP}^{+/+}$spinal cord (Fig. 10) indicating that $\operatorname{PrP}$ may be involved in regulation of Caspr function. In agreement with this idea, Western blot analysis showed that the levels of activated $140 \mathrm{kDa}$ Reelin autoproteolytic degradation product sampled within the lesion site in lesioned spinal cords were $86.7 \pm 33.3 \%$ higher in $\mathrm{PrP}^{-1-}$ versus $\mathrm{PrP}^{+/+}$animals $\left(n=3,{ }^{\star} p<0.05\right.$, paired $t$ test) (Fig. $\left.11 A\right)$. An increase in levels of activated, i. e., autoproteolytic, Reelin was accompanied by a $43.5 \pm 4.95 \%$ reduction in full-length Caspr levels and a proportional $80 \pm 13.3 \%$ increase in levels of the 50 $\mathrm{kDa}$ degradation product of Caspr at the lesion site in $\mathrm{PrP}^{-1-}$ mice $\left(n=3,{ }^{\star} p<0.05\right.$, paired $t$ test) (Fig. $11 A$ ), indicating 


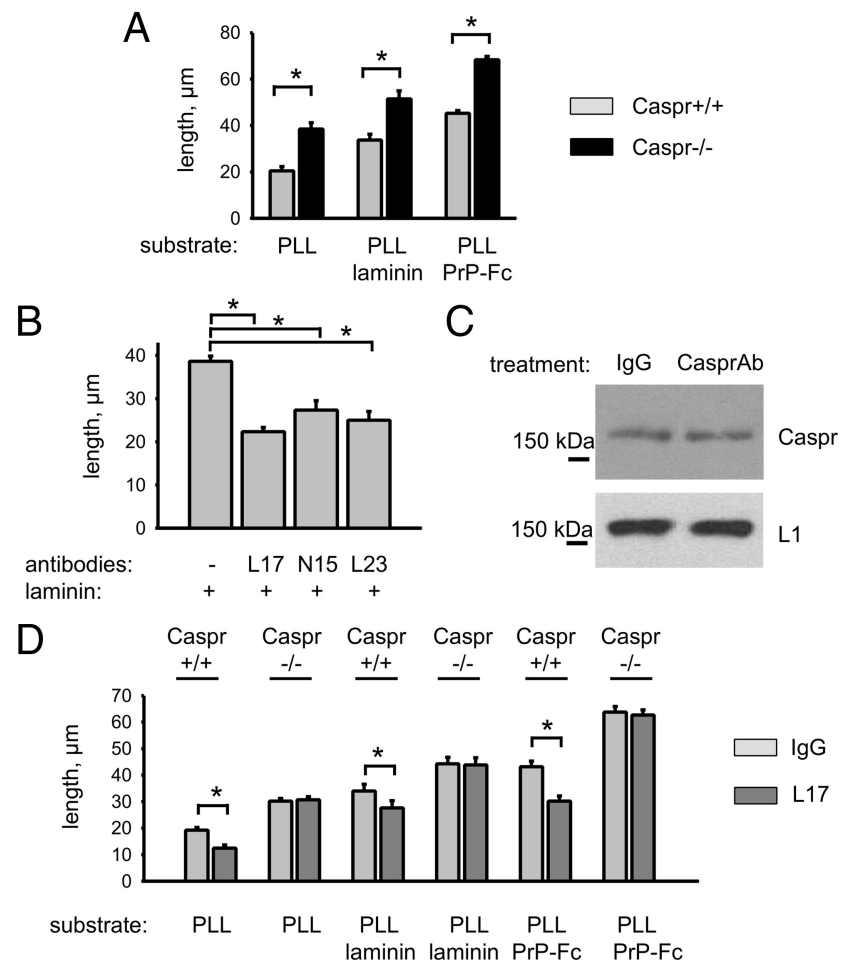

Figure 8. Caspr is involved in inhibition of neurite outgrowth. $\boldsymbol{A}$, Graph shows neurite

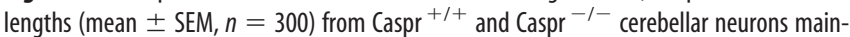
tained in culture on poly-L-lysine (PLL) substrate coated on glass coverslips alone, or in conjunction with laminin or PrP-Fc. Neurite lengths are increased in $\mathrm{Caspr}^{-1-}$ neurons versus Caspr $^{+1+}$ neurons on all substrates. ${ }^{*} p<0.05, t$ test. $\boldsymbol{B}$, Graph shows neurite lengths (mean \pm SEM, $n=300$ ) in Caspr ${ }^{+/+}$cerebellar neurons maintained on PLL substrate coated on glass coverslips in conjunction with laminin alone or together with polyclonal antibodies against three peptides in the extracellular domain of Caspr ( $(\mathrm{L} 17, \mathrm{~N} 15$, and L23). Neurite lengths are decreased in neurons grown in the presence of Caspr antibodies. ${ }^{*} p<0.05, t$ test. C, Lysates of cultured cerebellar neurons maintained on poly---lysine substrate coated with nonspecific rabbit lgs (IgG) or Caspr antibodies (L23) probed by Western blot with antibodies against Caspr and L1. Note that the levels of full-length Caspr are similar in both groups. The experiment was performed twice with the same effect. $\boldsymbol{D}$, Graph shows neurite lengths (mean $\pm \mathrm{SEM}, n=300$ ) in Caspr ${ }^{+/+}$and $\mathrm{Caspr}^{-/-}$cerebellar neurons maintained on PLL substrate coated on glass coverslips alone or in conjunction with laminin, PrP-Fc, nonspecific rabbit lgG, or antibodies against the extracellular domain of Caspr (L17). Neurite lengths are decreased in $\mathrm{Caspr}^{+/+}$but not in $\mathrm{Caspr}^{-1-}$ neurons grown in the presence of Caspr antibodies. ${ }^{*} p<0.05, t$ test.

enhanced proteolysis of Caspr. Interestingly, Western blot analysis showed that levels of full-length Caspr and its degradation product were not different in noninjured spinal cords of $\operatorname{PrP}^{+/+}$ and $\mathrm{PrP}^{-1-}$ mice (supplemental Fig. S2, available at www. jneurosci.org as supplemental material). Immunofluorescence labeling of noninjured spinal cords showed that Caspr nearly exclusively accumulated at paranodal regions in noninjured spinal cords of both $\mathrm{PrP}^{+/+}$and $\mathrm{PrP}^{-/-}$mice (supplemental Fig. S2, available at www.jneurosci.org as supplemental material). Together, these data suggest that PrP protects Caspr when it is located outside of the paranodes in growing or regenerating axons, while the protective role of $\operatorname{PrP}$ is diminished in paranodes. The presence of the $50 \mathrm{kDa}$ degradation product in the mature noninjured spinal cords, however, indicates that proteolytic processing of Caspr also takes place in paranodes, probably independently of PrP.

Enhanced proteolysis of Caspr at the sites of spinal cord lesion in $\mathrm{PrP}^{-l-}$ mice correlated with increased numbers of axons caudal to the lesion site in $\operatorname{PrP}^{-1-}$ versus $\operatorname{PrP}^{+/+}$animals. Numbers of catecholaminergic $\left(\mathrm{TH}^{+}\right)$and serotonergic $\left(5-\mathrm{HT}^{+}\right)$axons
A

- aprotinin

+ aprotinin
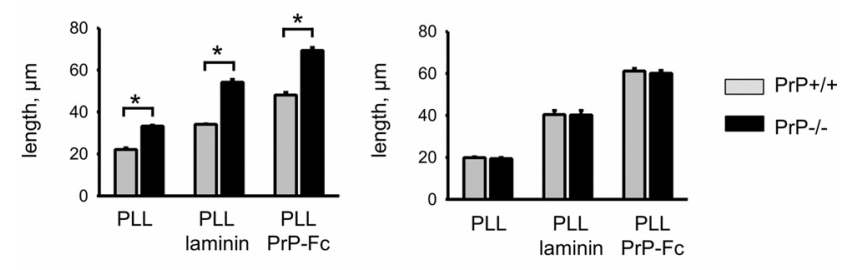

B
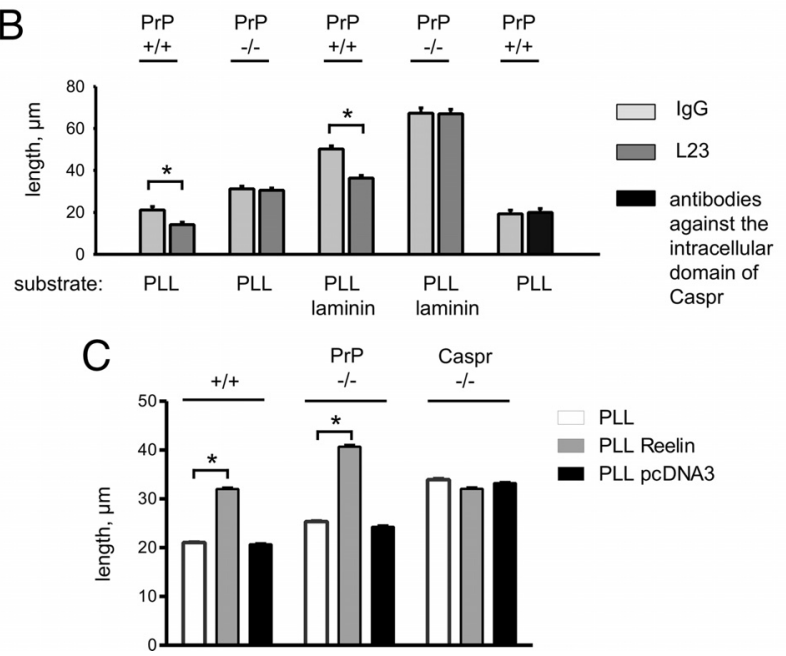

Figure 9. $\mathrm{PrP}^{-1-}$ neurons are less responsive than $\mathrm{PrP}^{+/+}$neurons to Caspr-mediated inhibition of neurite outgrowth. $A$, Graph shows neurite lengths (mean \pm SEM, $n=300$ ) from $\mathrm{PrP}^{+/+}$and $\mathrm{PrP}^{-1-}$ cerebellar neurons maintained on poly-L-lysine (PLL) substrate coated on glass coverslips alone or in conjunction with laminin or PrP-Fc. Neurons were grown in either the presence or absence of aprotinin. In the absence of aprotinin, neurites in $\mathrm{PrP}^{-1-}$ neurons are longer than those in $\mathrm{PrP}^{+/+}$neurons. This effect is lost in the presence of aprotinin. ${ }^{*} p<$ $0.05, t$ test. $B$, Graph shows neurite lengths (mean \pm SEM, $n=300$ ) in $\mathrm{PrP}^{+/+}$and PrP ${ }^{-/-}$ cerebellar neurons maintained on PLL substrate coated on glass coverslips alone or in conjunction with laminin, nonspecific rabbit immunoglobulins (lgG), antibodies against the extracellular (L23), or intracellular domain of Caspr. Note that antibodies against the extracellular domain of Caspr inhibit neurite outgrowth in $\operatorname{PrP}^{+/+}$but not $\operatorname{PrP}^{-1-}$ neurons. ${ }^{*} p<0.05, t$ test. C, Graph shows neurite lengths (mean $\pm \mathrm{SEM}, n=70$ ) in wild type, $\mathrm{PrP}^{-1-}$, and $\mathrm{Caspr}^{-1-}$ cerebellar neurons maintained on PLL substrate coated on glass coverslips alone or in conjunction with conditioned media from $\mathrm{CHO}$ cells transfected with Reelin or pcDNA3. Note that Reelin promotes neurite outgrowth in wild-type and $\mathrm{PrP}^{-1-}$ but not $\mathrm{Caspr}^{-1-}$ neurons. ${ }^{*} p<0.05, t$ test.

beyond an arbitrarily selected border $250 \mu \mathrm{m}$ caudal to the lesion site 6 weeks after the injury were twofold higher in $\mathrm{PrP}^{-1-}$ versus $\mathrm{PrP}^{+/+}$mice (Fig. $11 \mathrm{~B}$ ). The increase in the number of axonal fibers caudally to the lesion site, representing either axons that have grown through the lesion site or newly formed branches of the spared axons, thus suggests a more conducive tissue environment for axonal growth in regenerating spinal cord of $\mathrm{PrP}^{-1-}$ versus $\mathrm{PrP}^{+/+}$mice. It is unlikely that this increase in the number of regenerated axons was due to a lower susceptibility to damage or astrogliotic scarring in $\operatorname{PrP}^{-1-}$ mice, since the mean volume of the lesion scar in $\mathrm{PrP}^{+/+}$and $\mathrm{PrP}^{-1-}$ mice was similar at 6 weeks after injury $\left(1.25 \pm 0.11\right.$ vs $1.35 \pm 0.14 \mathrm{~mm}^{3} ; p>0.05$, $t$ test $)$.

Next, recovery of locomotor functions in $\operatorname{PrP}^{-1-}$ mice and their $\mathrm{PrP}^{+/+}$littermates was assessed at several time points after spinal cord lesion. Spinal cord compression caused severe disabilities in both $\mathrm{PrP}^{+/+}$and $\mathrm{PrP}^{-1-}$ mice, as assessed by the BBB score 1 week after injury (Fig. 11C). Between 1 and 6 weeks after the lesion, locomotor function improved in both genotypes, but improvement was greater in $\operatorname{PrP}^{-1-}$ mice than in their $\operatorname{PrP}^{+/+}$ littermates as estimated not only by BBB score values but also by 

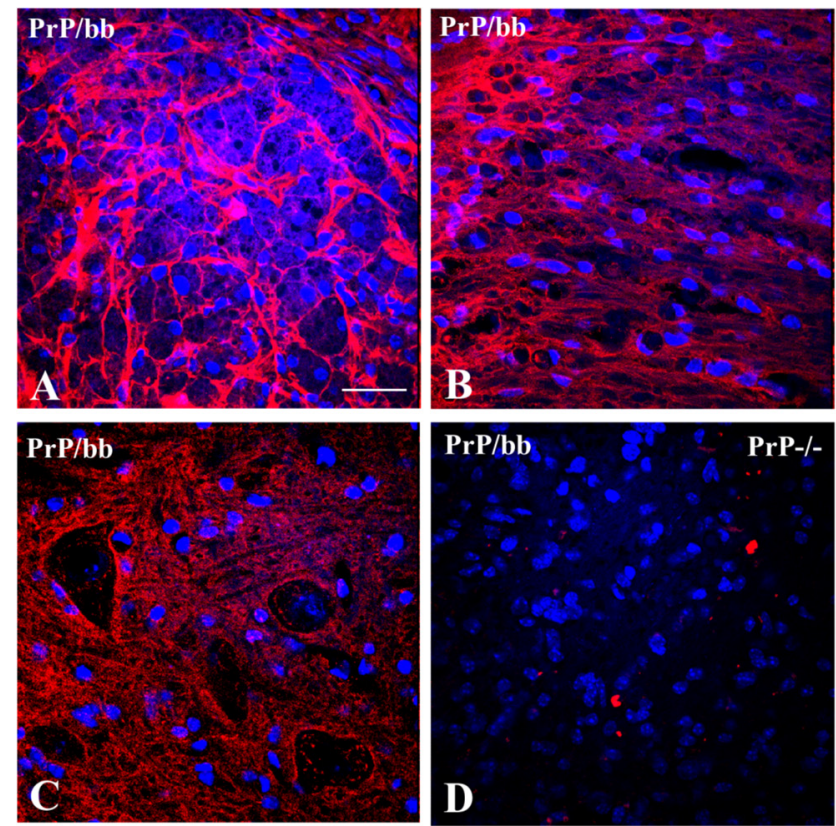

PrP-/-
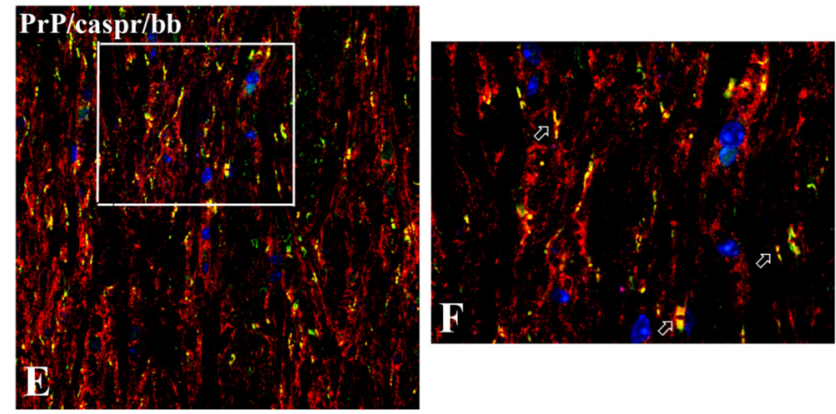

Figure 10. PrP and Caspr expression in the injured mouse spinal cord. $\boldsymbol{A}-\boldsymbol{C}$, Immunohistochemistry for $\operatorname{PrP}(\mathrm{red})$ at the lesion site $(\boldsymbol{A}), 500 \mu \mathrm{m}$ rostrally in the thoracic spinal cord $(\boldsymbol{B})$, and in the lumbar spinal cord gray matter (C).D, Immunohistochemistry for PrP at the lesion site of a $\operatorname{PrP}^{-1-}$ mouse spinal cord shows no specific staining. $\boldsymbol{E}$, Double immunohistochemistry for $\operatorname{PrP}\left(\right.$ red) and caspr (green) in the white matter of the injured PrP ${ }^{+/+}$spinal cord. $\boldsymbol{F}$, Higher magnification of the square in $\boldsymbol{E}$. Arrows point to the nodes of Ranvier. On all panels nuclei are counterstained with bisbenzamide (bb, blue). Scale bar: (in $\boldsymbol{A}) \boldsymbol{A}-\boldsymbol{E}, 20 \mu \mathrm{m} ; \boldsymbol{F}, 10 \mu \mathrm{m}$.

foot-stepping angle, rump-height index, and extension-flexion ratio (Fig. 11C). Foot-stepping angle is a parameter that describes plantar-stepping ability, previously shown to correlate well with the BBB score, whereas rump-height index and extension-flexion ratio measure the ability of lower limbs to support body weight and perform voluntary movements without weight support, respectively (Apostolova et al., 2006). $\mathrm{PrP}^{-1-}$ mice had better locomotor functions at 3 and 6 weeks after injury as estimated by all measured parameters, indicating better preserved and/or reestablished connections between the lumbar spinal cord and the higher brain structures compared with their $\mathrm{PrP}^{+/+}$littermates. However, numbers of correct steps made by the animals during inclined ladder climbing, reduced to approximately zero in both genotypes 1 week after injury, did not improve with time in neither $\mathrm{PrP}^{+/+}$nor $\mathrm{PrP}^{-/-}$mice (data not shown). The ladderclimbing test allows estimation of the ability to perform precise, coordinated movements requiring the highest degree of supraspinal control, which was not reestablished after being severed in either group of mice. From our analysis, we conclude that after spinal cord injury there is an overall improved recovery in $\mathrm{PrP}^{-/-}$mice compared with their $\mathrm{PrP}^{+/+}$littermates.

\section{Discussion}

In recent years, increasing interest has focused on the characterization of the role of the cellular form of PrP in neural cell interactions. PrP is a ubiquitously expressed small glycoprotein that displays functional properties of a cell adhesion molecule. It is localized at the cell surface via a GPI anchor and hence accumulates in cholesterol-enriched lipid microdomains or rafts. Interest in PrP also derives from its involvement in prion diseases that are caused by a conformationally altered insoluble form of PrP that accumulates in the brain as aggregates (Prusiner, 1998; Weissmann and Flechsig, 2003). Mutations in PrP causing aggregate formation have been linked to the Gerstmann-Sträussler-Scheinker syndrome, familial fatal insomnia, sporadic Creutzfeld-Jakob disease, and certain forms of dementia with cerebellar disorder and myopathy (Hsiao et al., 1989; Collinge, 1997).

In the present study we have investigated the functional interplay between $\mathrm{PrP}$ and two other glycoproteins involved in morphogenetic events in the developing nervous system: Caspr and Reelin. While the cellular form of PrP has been linked to neurite outgrowth and neuronal survival (Graner et al., 2000; Zanata et al., 2002; Chen et al., 2003; Santuccione et al., 2005; Lima et al., 2007), the contactin-associated protein Caspr has not been directly linked to neurite outgrowth, although its direct interaction with contactin would suggest such a function, since this GPIlinked Ig superfamily adhesion molecule promotes axonal growth (Falk et al., 2002). Caspr also interacts with the receptorlike protein tyrosine phosphatase RTPT $\beta$ (Peles et al., 1997), which induces neurite outgrowth by binding to contactin (Sakurai et al., 1997). Contactin, in turn, functionally interacts with $\beta_{1}$ integrin, a cell surface receptor for extracellular matrix ligands, an interaction that has been reported to be neurite outgrowth promoting (Treubert and Brummendorf, 1998). Caspr has been also reported to associate with $\beta_{1}$ integrin in the CNS (DenisenkoNehrbass et al., 2003). Caspr is further involved in a network of interactions in that it inhibits the binding of contactin to the $\mathrm{L} 1 \mathrm{Ig}$ family molecule neurofascin (Gollan et al., 2003). However, until now these interactions of Caspr with other molecules have been viewed mainly in the context of neuron-glia interactions at the node of Ranvier. As a third player in the neurite outgrowth regulating activities of PrP and Caspr, we introduce Reelin, an extracellular matrix glycoprotein that has been studied in terms of dendrite and axon development and neurogenesis (Hack et al., 2002; Kim et al., 2002; Niu et al., 2004; Forster et al., 2006; Won et al., 2006; Lorenzetto et al., 2008). A relation to neurite outgrowth for Reelin is again indicated by its capacity to interact with integrins (Dulabon et al., 2000; Schmid et al., 2005). Reelin also promotes neurite outgrowth through its interactions with the very low-density lipoprotein receptor and apolipoprotein E receptor via tyrosine phosphorylation of disabled-1 (D'Arcangelo et al., 1999; Hiesberger et al., 1999).

In the present study we show a novel relationship between $\operatorname{PrP}$, Caspr, and Reelin in the context of neurite outgrowth regulation. Clustering of Caspr at the cell surface of cultured cerebellar neurons inhibits neurite outgrowth, indicating that Caspr is a negative regulator of neurite outgrowth. PrP, by its direct interaction with Caspr at the cell surface, inhibits Caspr shedding from the cell surface, thereby potentiating the inhibitory effect of Caspr in neurite outgrowth in vitro. This new role for PrP in potentiation of neurite outgrowth inhibition does not contradict previous data on its outgrowth-promoting activities. On the contrary, it suggests an interesting scenario in which PrP promotes neurite outgrowth in the absence of Caspr activity. By maintain- 

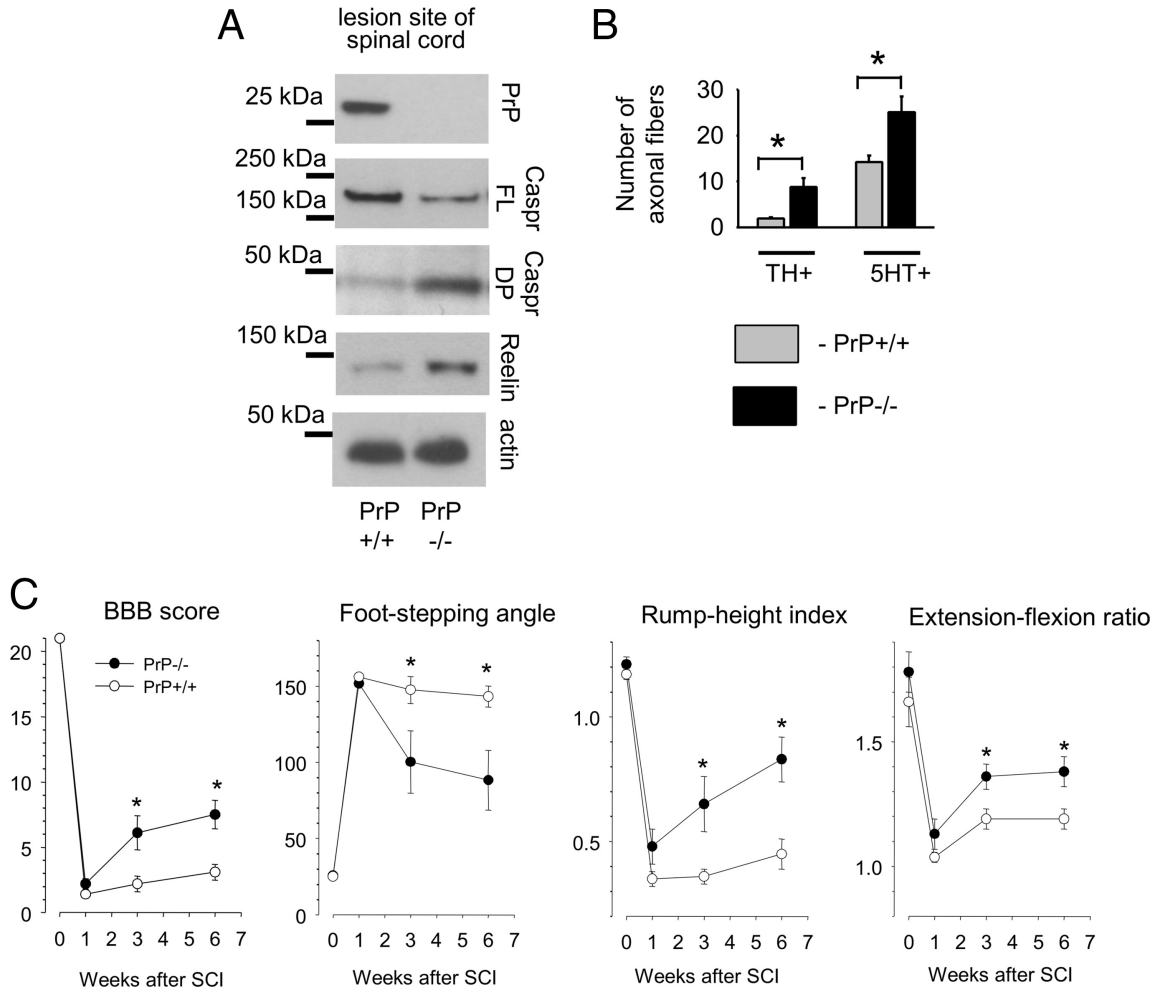

Figure 11. Enhanced Caspr proteolysis at the spinal cord lesion site correlates with increased axonal outgrowth and improved locomotor recovery in $\mathrm{PrP}^{-1-}$ versus $\mathrm{PrP}^{+/+}$mice after spinal cord injury. $\boldsymbol{A}$, Homogenates of the injured spinal cords from $\mathrm{PrP}^{+/+}$and $\mathrm{PrP}^{-1-}$ mice sampled at the lesion site were probed by Western blot with the indicated antibodies. Note decreased levels of the full-length (FL) Caspr and increased levels of the $50 \mathrm{kDa}$ degradation product (DP) of Caspr and $140 \mathrm{kDa}$ form of Reelin in $\operatorname{PrP}^{-1-}$ versus $\mathrm{PrP}^{+/+}$samples. Actin served as a loading control. $\boldsymbol{B}$, Graph shows numbers of catecholaminergic $\left(\mathrm{TH}^{+}\right)$and serotonergic $\left(5 \mathrm{HT}^{+}\right)$axons projecting beyond a line drawn $250 \mu \mathrm{m}$ caudally to the lesion site counted in spaced serial parasagittal sections from the injured spinal cords of $\mathrm{PrP}^{+/+}$and $\mathrm{PrP}^{-1-}$ mice killed 6 weeks after injury. Note increased numbers of $\mathrm{TH}^{+}$ and $5-\mathrm{HT}^{+}$fibers in $\mathrm{PrP}^{-1-}$ versus $\mathrm{PrP}^{+/+}$mice. ${ }^{*} p<0.05, t$ test. C, Shown are mean \pm SEM values of open-field locomotion (BBB) scores, foot-stepping angles, rump-height indices, and extension-flexion ratios before surgery ( $\mathrm{d} 0$ ) and at 1,3 , and 6 weeks after spinal cord injury $(\mathrm{SCl}) .{ }^{*} p<0.05$, significant differences between group mean values at a given time period (one-way ANOVA for repeated measurements with Tukey's post hoc test; $n=10$ mice per genotype).

ing high Caspr levels at the cell surface, PrP allows neurites to respond promptly to Caspr activation that would arrest neurite outgrowth when the proper targets are reached.

In the present study, we confirmed Reelin's function as a protease rather than as a ligand for integrins or lipoprotein receptors. This proteolytic activity of Reelin (Quattrocchi et al., 2002) appears to play a role in regulating the Caspr-dependent inhibition of neurite outgrowth of cerebellar neurons; in the absence of $\mathrm{PrP}$, Reelin proteolytically cleaves the extracellular domain of Caspr, thus reducing the capacity of Caspr to decrease neurite outgrowth. The functions of the extracellular $50 \mathrm{kDa}$ fragment of Caspr produced by Reelin are not known, but it is possible that by itself it also plays an outgrowth-promoting role. Interestingly, levels of the activated $140 \mathrm{kDa}$ Reelin proteolytic fragment are increased in PrP-deficient brains. This observation suggests that PrP not only protects Caspr from Reelin-mediated proteolysis by directly associating with Caspr, but also that the activation of Reelin is down regulated by unknown mechanisms in the presence of PrP. Whether these effects are dependent also on Casprassociated proteins, such as contactin, remains to be seen.

In the context of our study it is noteworthy that differentiation of granule cells and cerebellar network formation is retarded in PrP-deficient mice, confirming the role of PrP in brain development (Prestori et al., 2008). In our present study, the potentiating effect of PrP on inhibition of neurite outgrowth was tested not only in vitro but also in vivo; in agreement with our in vitro data, constitutive absence of $\mathrm{PrP}$ in mice leads to enhanced regeneration after spinal cord injury in terms of recovery of locomotor functions and regrowth of serotonergic and adrenergic axons into the caudal part of the lesioned spinal cord of adult mice. These results are interpretable in the context of PrP's ability to enhance the inhibitory activity of Caspr on neurite outgrowth by neutralizing the Reelin-mediated proteolysis of Caspr. In agreement with this, Reelin ${ }^{-1-}$ mice show impaired nerve regeneration after peripheral nerve injury (Lorenzetto et al., 2008). Recent observations also provide evidence that Reelin is expressed and secreted by oligodendrocytes (Osterhout and Siebert, 2009). Our data call for analysis of axonal regrowth in Caspr-deficient mice that should provide evidence of a role for Caspr in inhibiting axonal regrowth and locomotor recovery after spinal cord injury. However, this experiment could not be performed due to the very high mortality of Caspr-deficient mice within a week after the spinal cord injury. Further research using more refined methods of Caspr knock-down in vivo should help to address this question.

Although the associations between $\mathrm{PrP}$, Caspr, and Reelin in vivo are likely to be more complex than depicted in the present study, we view our results on the functional interplay between the three molecules in vitro to allow our present interpretation. It is unlikely that the enhanced recovery of locomotor functions in spinal cord-lesioned PrP deficient mice are due to more general abnormalities, since the anatomy of their CNS is apparently normal and functional abnormalities in these mice are very subtle (Bueler et al., 1992). However, enhanced proteolytic activity in PrP-deficient brains and in the CNS may well contribute to enhanced locomotor recovery after the spinal cord injury. Whether other inhibitory molecules are targets of Reelin's proteolytic activity remains to be investigated.

In view of our findings, the observed abnormalities in the reeler mutant and Caspr-deficient mice call for a comparison of their phenotypes in the context of the functional interplay between Reelin, Caspr, and PrP. The molecular and cellular mechanisms underlying the ataxic behavior of reeler mutant mice have been attributed to cell migration defects in the cerebellar and cerebral cortices (Magdaleno et al., 2002; Won et al., 2006). It is not known, however, how these relate to the absence of the proteolytic activity of Reelin. The ataxic defects of Caspr-deficient mice have been mostly related to the abnormal structure of nodes of Ranvier in the central and peripheral nervous systems (Bhat et al., 2001), but they also could be related in view of our present observations in the context of an altered balance between neurite outgrowth-promoting and neurite outgrowth-inhibitory cues. The relation of these molecules to transmitter receptors, ion channels, and ion transporters that have emerged recently as im- 
portant partners in recognition molecule function also needs to be investigated.

\section{References}

Apostolova I, Irintchev A, Schachner M (2006) Tenascin-R restricts posttraumatic remodeling of motoneuron innervation and functional recovery after spinal cord injury in adult mice. J Neurosci 26:7849-7859.

Appel F, Holm J, Conscience JF, Schachner M (1993) Several extracellular domains of the neural cell adhesion molecule $\mathrm{Ll}$ are involved in neurite outgrowth and cell body adhesion. J Neurosci 13:4764-4775.

Basso DM, Beattie MS, Bresnahan JC (1995) A sensitive and reliable locomotor rating scale for open field testing in rats. J Neurotrauma 12:1-21.

Beggs HE, Soriano P, Maness PF (1994) NCAM-dependent neurite outgrowth is inhibited in neurons from Fyn-minus mice. J Cell Biol 127:825-833.

Beggs HE, Baragona SC, Hemperly JJ, Maness PF (1997) NCAM140 interacts with the focal adhesion kinase p125(fak) and the SRC-related tyrosine kinase p59(fyn). J Biol Chem 272:8310-8319.

Bhat MA, Rios JC, Lu Y, Garcia-Fresco GP, Ching W, St Martin M, Li J, Einheber S, Chesler M, Rosenbluth J, Salzer JL, Bellen HJ (2001) Axonglia interactions and the domain organization of myelinated axons requires neurexin IV/Caspr/Paranodin. Neuron 30:369-383.

Bodrikov V, Leshchyns'ka I, Sytnyk V, Overvoorde J, den Hertog J, Schachner M (2005) RPTPalpha is essential for NCAM-mediated p59fyn activation and neurite elongation. J Cell Biol 168:127-139.

Bodrikov V, Sytnyk V, Leshchyns'ka I, den Hertog J, Schachner M (2008) NCAM induces CaMKIIalpha-mediated RPTPalpha phosphorylation to enhance its catalytic activity and neurite outgrowth. J Cell Biol 182:1185-1200.

Bueler H, Fischer M, Lang Y, Bluethmann H, Lipp HP, DeArmond SJ, Prusiner SB, Aguet M, Weissmann C (1992) Normal development and behaviour of mice lacking the neuronal cell-surface PrP protein. Nature 356:577-582.

Chen S, Mantei N, Dong L, Schachner M (1999) Prevention of neuronal cell death by neural adhesion molecules L1 and CHL1. J Neurobiol 38:428-439.

Chen S, Mange A, Dong L, Lehmann S, Schachner M (2003) Prion protein as trans-interacting partner for neurons is involved in neurite outgrowth and neuronal survival. Mol Cell Neurosci 22:227-233.

Collinge J (1997) Human prion diseases and bovine spongiform encephalopathy (BSE). Hum Mol Genet 6:1699-1705.

Collinge J, Whittington MA, Sidle KC, Smith CJ, Palmer MS, Clarke AR, Jefferys JG (1994) Prion protein is necessary for normal synaptic function. Nature 370:295-297.

Curtis R, Green D, Lindsay RM, Wilkin GP (1993) Up-regulation of GAP-43 and growth of axons in rat spinal cord after compression injury. J Neurocytol 22:51-64.

D'Arcangelo G, Homayouni R, Keshvara L, Rice DS, Sheldon M, Curran T (1999) Reelin is a ligand for lipoprotein receptors. Neuron 24:471-479.

Denisenko-Nehrbass N, Goutebroze L, Galvez T, Bonnon C, Stankoff B, Ezan P, Giovannini M, Faivre-Sarrailh C, Girault JA (2003) Association of Caspr/paranodin with tumor suppressor schwannomin/merlin and beta 1 integrin in the central nervous system. J Neurochem 84:209-221.

Dulabon L, Olson EC, Taglienti MG, Eisenhuth S, McGrath B, Walsh CA, Kreidberg JA, Anton ES (2000) Reelin binds alpha3betal integrin and inhibits neuronal migration. Neuron 27:33-44.

Einheber S, Zanazzi G, Ching W, Scherer S, Milner TA, Peles E, Salzer JL (1997) The axonal membrane protein Caspr, a homologue of neurexin $\mathrm{IV}$, is a component of the septate-like paranodal junctions that assemble during myelination. J Cell Biol 139:1495-1506.

Faivre-Sarrailh C, Gauthier F, Denisenko-Nehrbass N, Le Bivic A, Rougon G, Girault JA (2000) The glycosylphosphatidyl inositol-anchored adhesion molecule F3/contactin is required for surface transport of paranodin/ contactin-associated protein (Caspr). J Cell Biol 149:491-502.

Falk J, Bonnon C, Girault JA, Faivre-Sarrailh C (2002) F3/contactin, a neuronal cell adhesion molecule implicated in axogenesis and myelination. Biol Cell 94:327-334.

Forster E, Jossin Y, Zhao S, Chai X, Frotscher M, Goffinet AM (2006) Recent progress in understanding the role of Reelin in radial neuronal migration, with specific emphasis on the dentate gyrus. Eur J Neurosci 23:901-909.

Gauczynski S, Peyrin JM, Haik S, Leucht C, Hundt C, Rieger R, Krasemann S, Deslys JP, Dormont D, Lasmezas CI, Weiss S (2001) The 37-kDa/67-
$\mathrm{kDa}$ laminin receptor acts as the cell-surface receptor for the cellular prion protein. EMBO J 20:5863-5875.

Gollan L, Salomon D, Salzer JL, Peles E (2003) Caspr regulates the processing of contactin and inhibits its binding to neurofascin. J Cell Biol 163:1213-1218.

Graner E, Mercadante AF, Zanata SM, Forlenza OV, Cabral AL, Veiga SS, Juliano MA, Roesler R, Walz R, Minetti A, Izquierdo I, Martins VR, Brentani RR (2000) Cellular prion protein binds laminin and mediates neuritogenesis. Brain Res Mol Brain Res 76:85-92.

Hack I, Bancila M, Loulier K, Carroll P, Cremer H (2002) Reelin is a detachment signal in tangential chain-migration during postnatal neurogenesis. Nat Neurosci 5:939-945.

Hiesberger T, Trommsdorff M, Howell BW, Goffinet A, Mumby MC, Cooper JA, Herz J (1999) Direct binding of Reelin to VLDL receptor and ApoE receptor 2 induces tyrosine phosphorylation of disabled- 1 and modulates tau phosphorylation. Neuron 24:481-489.

Hsiao K, Baker HF, Crow TJ, Poulter M, Owen F, Terwilliger JD, Westaway D, Ott J, Prusiner SB (1989) Linkage of a prion protein missense variant to Gerstmann-Straussler syndrome. Nature 338:342-345.

Jakovcevski I, Wu J, Karl N, Leshchyns'ka I, Sytnyk V, Chen J, Irintchev A, Schachner M (2007) Glial scar expression of CHL1, the close homolog of the adhesion molecule L1, limits recovery after spinal cord injury. J Neurosci 27:7222-7233.

Jakovcevski I, Siering J, Hargus G, Karl N, Hoelters L, Djogo N, Yin S, Zecevic N, Schachner M, Irintchev A. (2009) Close homologue of adhesion molecule L1 promotes survival of Purkinje and granule cells and granule cell migration during murine cerebellar development. J Comp Neurol 513: 496-510.

Joshi M, Fehlings MG (2002) Development and characterization of a novel, graded model of clip compressive spinal cord injury in the mouse: Part 1. Clip design, behavioral outcomes, and histopathology. J Neurotrauma 19:175-190.

Kim HM, Qu T, Kriho V, Lacor P, Smalheiser N, Pappas GD, Guidotti A, Costa E, Sugaya K (2002) Reelin function in neural stem cell biology. Proc Natl Acad Sci U S A 99:4020-4025.

Kleene R, Loers G, Langer J, Frobert Y, Buck F, Schachner M (2007) Prion protein regulates glutamate-dependent lactate transport of astrocytes. J Neurosci 27:12331-12340.

Leshchyns'ka I, Sytnyk V, Morrow JS, Schachner M (2003) Neural cell adhesion molecule (NCAM) association with PKCbeta2 via betaI spectrin is implicated in NCAM-mediated neurite outgrowth. J Cell Biol 161:625-639.

Leshchyns'ka I, Sytnyk V, Richter M, Andreyeva A, Puchkov D, Schachner M (2006) The adhesion molecule CHL1 regulates uncoating of clathrincoated synaptic vesicles. Neuron 52:1011-1025.

Lima FR, Arantes CP, Muras AG, Nomizo R, Brentani RR, Martins VR (2007) Cellular prion protein expression in astrocytes modulates neuronal survival and differentiation. J Neurochem 103:2164-2176.

Lopes MH, Hajj GN, Muras AG, Mancini GL, Castro RM, Ribeiro KC, Brentani RR, Linden R, Martins VR (2005) Interaction of cellular prion and stressinducible protein 1 promotes neuritogenesis and neuroprotection by distinct signaling pathways. J Neurosci 25:11330-11339.

Lorenzetto E, Panteri R, Marino R, Keller F, Buffelli M (2008) Impaired nerve regeneration in reeler mice after peripheral nerve injury. Eur J Neurosci 27:12-19.

Magdaleno S, Keshvara L, Curran T (2002) Rescue of ataxia and preplate splitting by ectopic expression of Reelin in reeler mice. Neuron 33:573-586.

Mouillet-Richard S, Ermonval M, Chebassier C, Laplanche JL, Lehmann S, Launay JM, Kellermann O (2000) Signal transduction through prion protein. Science 289:1925-1928.

Niu S, Renfro A, Quattrocchi CC, Sheldon M, D’Arcangelo G (2004) Reelin promotes hippocampal dendrite development through the VLDLR/ ApoER2-Dab1 pathway. Neuron 41:71-84.

Osterhout DJ, Siebert JR (2009) Oligodendrocyte progenitor cells express and secrete reelin. Soc Neurosci Abstract 35:126.10.

Paratcha G, Ledda F, Baars L, Coulpier M, Besset V, Anders J, Scott R, Ibanez CF (2001) Released GFRalpha1 potentiates downstream signaling, neuronal survival, and differentiation via a novel mechanism of recruitment of c-Ret to lipid rafts. Neuron 29:171-184.

Peles E, Salzer JL (2000) Molecular domains of myelinated axons. Curr Opin Neurobiol 10:558-565. 
Peles E, Nativ M, Lustig M, Grumet M, Schilling J, Martinez R, Plowman GD, Schlessinger J (1997) Identification of a novel contactin-associated transmembrane receptor with multiple domains implicated in proteinprotein interactions. EMBO J 16:978-988.

Pfenninger KH, Ellis L, Johnson MP, Friedman LB, Somlo S (1983) Nerve growth cones isolated from fetal rat brain: subcellular fractionation and characterization. Cell 35:573-584.

Prestori F, Rossi P, Bearzatto B, Lainé J, Necchi D, Diwakar S, Schiffmann SN, Axelrad H, D'Angelo E (2008) Altered neuron excitability and synaptic plasticity in the cerebellar granular layer of juvenile prion protein knockout mice with impaired motor control. J Neurosci 28:7091-7103.

Prusiner SB (1998) Prions. Proc Natl Acad Sci U S A 95:13363-13383.

Quattrocchi CC, Wannenes F, Persico AM, Ciafre SA, D’Arcangelo G, Farace MG, Keller F (2002) Reelin is a serine protease of the extracellular matrix. J Biol Chem 277:303-309.

Rice DS, Curran T (2001) Role of the reelin signaling pathway in central nervous system development. Annu Rev Neurosci 24:1005-1039.

Rieger R, Edenhofer F, Lasmezas CI, Weiss S (1997) The human 37-kDa laminin receptor precursor interacts with the prion protein in eukaryotic cells. Nat Med 3:1383-1388.

Sakurai T, Lustig M, Nativ M, Hemperly JJ, Schlessinger J, Peles E, Grumet M (1997) Induction of neurite outgrowth through contactin and Nr-CAM by extracellular regions of glial receptor tyrosine phosphatase beta. J Cell Biol 136:907-918.

Santuccione A, Sytnyk V, Leshchyns'ka I, Schachner M (2005) Prion protein recruits its neuronal receptor NCAM to lipid rafts to activate p59fyn and to enhance neurite outgrowth. J Cell Biol 169:341-354.

Scherer SS (1999) Nodes, paranodes, and incisures: from form to function. Ann NY Acad Sci 883:131-142.

Schmid RS, Jo R, Shelton S, Kreidberg JA, Anton ES (2005) Reelin, integrin and $\mathrm{DAB} 1$ interactions during embryonic cerebral cortical development. Cereb Cortex 15:1632-1636.

Schmidt A, Hannah MJ, Huttner WB (1997) Synaptic-like microvesicles of neuroendocrine cells originate from a novel compartment that is continuous with the plasma membrane and devoid of transferrin receptor. J Cell Biol 137:445-458.

Schmitt-Ulms G, Legname G, Baldwin MA, Ball HL, Bradon N, Bosque PJ, Crossin KL, Edelman GM, DeArmond SJ, Cohen FE, Prusiner SB (2001) Binding of neural cell adhesion molecules (N-CAMs) to the cellular prion protein. J Mol Biol 314:1209-1225.

Sytnyk V, Leshchyns'ka I, Delling M, Dityateva G, Dityatev A, Schachner M (2002) Neural cell adhesion molecule promotes accumulation of TGN organelles at sites of neuron-to-neuron contacts. J Cell Biol 159:649-661.

Tissir F, Goffinet AM (2003) Reelin and brain development. Nat Rev Neurosci 4:496-505.

Treubert U, Brummendorf T (1998) Functional cooperation of $\beta_{1}$-integrins and members of the Ig superfamily in neurite outgrowth induction. J Neurosci 18:1795-1805.

Trupp M, Scott R, Whittemore SR, Ibanez CF (1999) Ret-dependent and -independent mechanisms of glial cell line-derived neurotrophic factor signaling in neuronal cells. J Biol Chem 274:20885-20894.

Weissmann C, Flechsig E (2003) PrP knock-out and PrP transgenic mice in prion research. Br Med Bull 66:43-60.

Won SJ, Kim SH, Xie L, Wang Y, Mao XO, Jin K, Greenberg DA (2006) Reelin-deficient mice show impaired neurogenesis and increased stroke size. Exp Neurol 198:250-259.

Zanata SM, Lopes MH, Mercadante AF, Hajj GN, Chiarini LB, Nomizo R, Freitas AR, Cabral AL, Lee KS, Juliano MA, de Oliveira E, Jachieri SG, Burlingame A, Huang L, Linden R, Brentani RR, Martins VR (2002) Stress-inducible protein 1 is a cell surface ligand for cellular prion that triggers neuroprotection. EMBO J 21:3307-3316. 